\title{
Accounting for cross-country differences in wealth inequality
}

\section{Frank A. Cowell, Eleni Karagiannaki and Abigail McKnight}

\section{Contents}

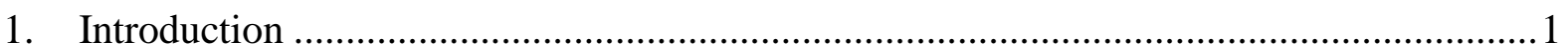

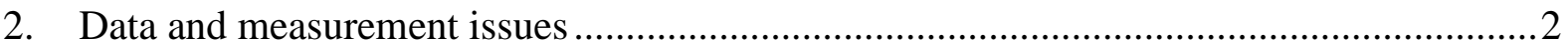

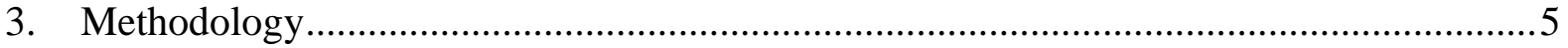

4. Analysing cross-country differences in the distribution of net worth ..............................

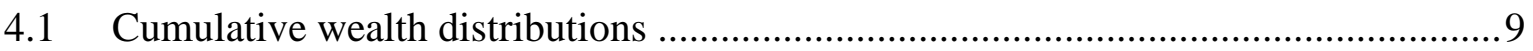

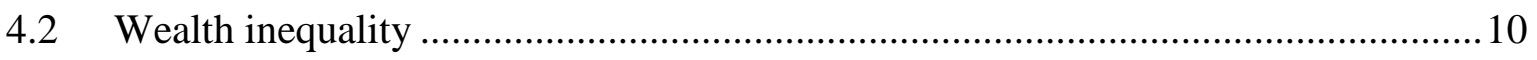

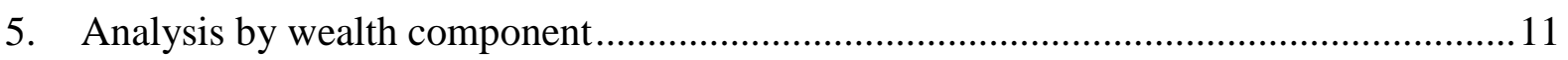

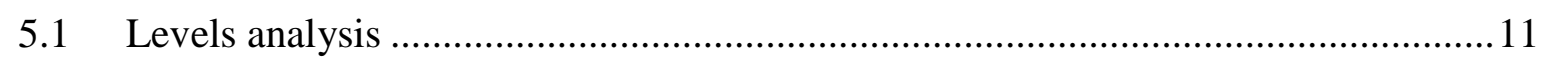

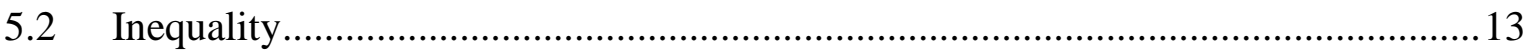

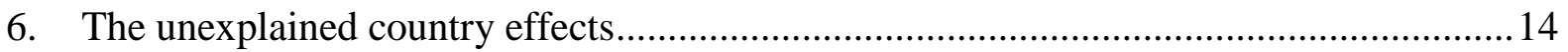

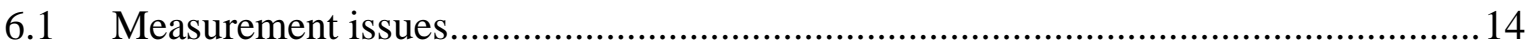

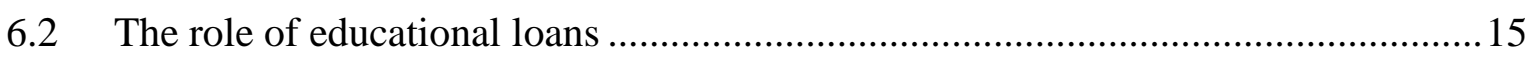

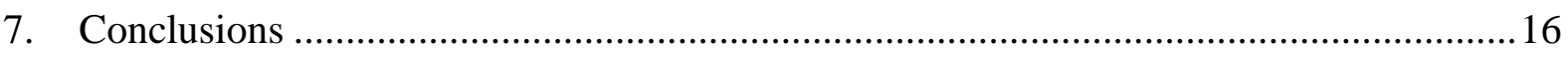

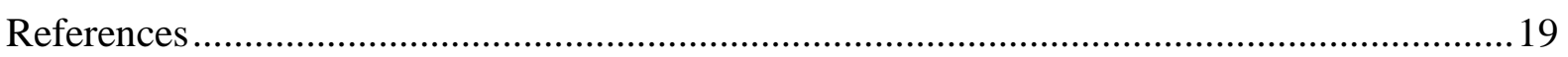

CASE/168

March 2013
Centre for Analysis of Social Exclusion

London School of Economics

Houghton Street

London WC2A $2 \mathrm{AE}$

CASE enquiries - tel: 02079556679 


\section{Centre for Analysis of Social Exclusion}

The Centre for the Analysis of Social Exclusion (CASE) is a multi-disciplinary research centre based at the London School of Economics and Political Science (LSE), within the Suntory and Toyota International Centres for Economics and Related Disciplines (STICERD). Our focus is on exploration of different dimensions of social disadvantage, particularly from longitudinal and neighbourhood perspectives, and examination of the impact of public policy.

In addition to our discussion paper series (CASEpapers), we produce occasional summaries of our research in CASEbriefs, and reports from various conferences and activities in CASEreports. All these publications are available to download free from our website. Limited printed copies are available on request.

For further information on the work of the Centre, please contact the Centre Manager, Jane Dickson, on:

Telephone: UK+20 79556679

Fax: $\quad$ UK+207955 6951

Email: $\quad$ j.dickson@1se.ac.uk

Web site: http://sticerd.lse.ac.uk/case

(C) Frank Cowell

Eleni Karagiannaki

Abigail McKnight

All rights reserved. Short sections of text, not to exceed two paragraphs, may be quoted without explicit permission provided that full credit, including (C) notice, is given to the source. 


\title{
Editorial Note and Acknowledgements
}

Frank Cowell is Professor of Economics at the London School of Economics and CASE Associate, Eleni Karagiannaki is a Research Officer and Abigail McKnight a Senior Research Fellow in CASE, at the London School of Economics. We are grateful for comments from seminar participants at the GINI project seminars in Amsterdam, Milan and London. The excellent staff and work of the Luxembourg Wealth Study at the LIS datacentre made this research possible. This research was funded by the European Union FP7 Growing Inequalities' Impacts (GINI) research project.

\begin{abstract}
This paper adopts a counterfactual decomposition analysis to analyse cross-country differences in the size of household wealth and levels of household wealth inequality. The findings of the paper suggest that the biggest share of cross-country differences is not due to differences in the distribution of household demographic and economic characteristics but rather reflect strong unobserved country effects.
\end{abstract}

Keywords: household wealth, wealth inequality, debt, housing assets, educational loans, age-wealth profiles, decomposition

JEL codes: C81, D31, D63, I24, I31

Contact details: Frank Cowell f.cowell@1se.ac.uk; Eleni Karagiannaki e.karagiannaki@1se.ac.uk; Abigail McKnight abigail.mcknight@1se.ac.uk CASE, London School of Economics, Houghton Street, London WC2 2AE 


\section{Introduction}

New comparable data suggest that the distribution of household wealth vary substantially across countries. In many instances the wealth inequality ranking of countries is very different from their respective ranking in terms of income inequality (Jäntti et al., 2008). Probably the most striking example is Sweden which despite being one of the most equal countries in terms of income distribution it is ranked as one of the most unequal countries in terms of wealth, even more so than the US. Probably Sweden is the most extreme example but there are several other instances where wealth and income inequality rankings are very different.

Obviously there are several reasons why country rankings in terms of wealth inequality may differ from that in terms of income inequality. Differences in institutional settings and economic environment will have a distinct effect on household wealth accumulation, over and above the impact of income, by affecting households saving motives and saving propensities. Cross-country differences in the importance of past inheritances will exacerbate the impact of the above-mentioned factors. Aside from these influences cross country differences in the distribution of household wealth may (at least to some extent) represent pure cross-country differences in the age composition and the household structure of their populations. Any assessment of cross-country differences in the distribution of household wealth needs to account for these types of factors. Furthermore the cross-country variation in household wealth may reflect country specific personal preferences (shaped by cultural and historical factors) for owning specific types of assets and debts.

In this paper we examine the contribution of cross-country differences in the distribution of a number of economic and demographic characteristics in accounting for cross country differences in the distribution of household wealth. The factors that we consider include age, household structure (i.e. the distribution of different household types), labour market status, educational attainment and income. In addition to investigating the overall effect of all these factors we also investigate the contribution of each of these factors separately. This analysis allows us to pin down the importance of different factors in explaining cross-country differences in households' wealth and their implications in explaining differences in household wealth inequality. The unexplained component (which may vary both across the distribution and across countries) will capture the effect of all unobserved crosscountry differences (including for example differences in welfare and tax systems, as well as various market regulations and constraints) which determine how a given population with given characteristics accumulate assets and debts. In order to better understand the importance of different factors in shaping wealth distributions in addition to estimating the overall wealth differences we investigate cross-country differences in the level and the distribution of different wealth components. 


\section{Data and measurement issues}

The data set used in this paper is drawn from the Luxemburg Wealth Study database (LWS), a cross-national database which currently provides harmonised wealth data for 12 industrialised countries. From this database we have selected five countries for our analysis: UK, Italy, Finland, Sweden and the US. The national original datasets are the British Household Panel Survey (BHPS, 2000) for the UK, the Survey of Household Income and Wealth (SHIW, 2002) for Italy, the Household Wealth Survey (1998) for Finland and the Wealth Survey (HINK, 2002) for Sweden. For the US the LWS database includes data from two national surveys: the Survey of Consumer Finances (SCF, 2001) and the Panel Study of Income Distribution (PSID, 2001). The latter is a general household survey with a special focus on income while the former a specialised wealth survey. A critical feature of the SCF is that it over-samples the wealthy and therefore has a better representation of the upper tail of the wealth distribution. ${ }^{1}$ In this paper we use data from both the SCF and the PSID to test the sensitivity of our results to survey design features. Although there are quite substantial methodological differences across the national surveys (including differences in sampling framework, survey design and the number and definition of wealth variables recorded in each survey), LWS managed to construct reasonably comparable variables for a number of wealth measures (for details about the database and the harmonization process see Sierminska et al, 2006). However, some comparability issues still remain (related mainly to variations in the underlying definitions, valuation criteria and methods) and these have to be borne in mind when analysing our results. In the final section of our paper we discuss some of these differences and their implications for accounting cross country differences in wealth inequality.

The measure of wealth that we use in this paper is total household net worth (the NW1 LWS variable). This is constructed as the sum of financial and non-financial assets of the households minus total household debt (i.e. sum of housing debt and non-housing debt - thereafter we will refer to the latter measures as financial debt). Financial assets include deposit accounts, stocks, bonds and mutual funds. Non-financial assets (housing assets thereafter) include own principal residence and investment real estate. Total debt refers to all outstanding loans, both home secured and non-home secured (including informal debt). A limitation of our study is that the measure of net worth that we use excludes business and pension assets (since data on these assets is only available for a subset of countries). Given the differential importance of these types of wealth in different countries, our comparison would - at least partly - reflect the omissions of these types of assets (Sierminska et al. 2006 provides a detailed discussion on this issue and a reconciliation between LWS and the national definitions of net worth). In addition to total net worth, we analyse wealth differences for four wealth components: gross financial assets, gross housing assets, net financial assets, housing equity as well as housing and financial debt. For some countries we are able

1 The SCF covers around 4,500 families. A booster sample, chosen on the basis of information contained in tax returns, is selected to disproportionately sample wealthy families (but excluding the wealthiest 400 families, defined by Forbes magazine). 
to look into even more disaggregated wealth components though the degree of disaggregation we can achieve with the data at hand is limited. All wealth data (as all monetary values in this paper) are transformed to constant 2005 prices (using the national CPI) and are converted at 2005 PPP-adjusted Euros (Euro area 16 countries) using the purchasing power parities for gross domestic product (GDP). ${ }^{2}$

Throughout our paper the unit of analysis is the household. In most of the countries this is defined as a group of people living in the same dwelling (irrespective of their kinship) and share household expenses. The only exception here is BHPS which does not incorporate the share of expenses requirement in its definition of household units. In Sweden although the household unit definition is very close to the one adopted in the other surveys, for individuals non-responding to the telephone interview (around 30 per cent), it was not possible to identify if they were cohabiting through registry data unless they had children in common. In this case, these individuals were classified as single person households. This means that in the Swedish survey the number of single person and single parent households is somewhat overestimated (Statistics Sweden, 2006).

Table 1 reports the mean and selected percentiles of household net worth for each of our five countries. For the reasons outlined above, for the US we present results based on PSID and the SCF. Confirming results from previous studies, the results of this table show that there exist very large cross-country differences in household net worth, differences that vary across the distribution. The US has the highest average levels of wealth ( $€ 207.0 \mathrm{k}$ based on SCF and $€ 158.1 \mathrm{k}$ based on PSID), followed in descending order by Italy (€163.6k), the UK (€116.7k), Finland (€66.5k) and Sweden $(€ 50.9 \mathrm{k})$. At lower wealth percentiles the lowest wealth levels are observed in Sweden, the US and Finland (in this order) while the highest in Italy and the UK. At higher points of the distribution on the other hand, the highest wealth levels are observed in the US and Italy while the lowest in Sweden and Finland. To illustrate how wealth varies across the whole distribution, in Figure 1 we plot the percentile distribution of net worth for each country.

Table 2 presents summary inequality indices for household net worth for each country. In terms of the Gini coefficient, Sweden and the US have the highest levels of inequality (at 0.89 and 0.83 (SCF) respectively) while Italy has the lowest $(0.60)$. Finland (0.68) and the UK (0.63) are positioned in the middle of these extremes. A similar picture emerges when percentile ratios are considered (see columns 3 and 4 of Table 2). Once again Sweden ${ }^{3}$ and the US exhibit the highest levels of wealth inequality while Italy the lowest. The ranking of Finland and the UK however depends on which wealth dispersion measures we consider. Finland has higher inequality than

2 Data source OECD Dataset 4: PPPs and exchange rates: Data extracted from http://stats.oecd.org/OECDStat_Metadata/ShowMetadata.ashx?Dataset=SNA_TABLE4\&Sho wOnWeb=true\&Lang=en (extracted on 11/10/2010 from OECD.stat)

3 It is not possible to compute the P25/P50 ratio for Sweden as household net worth at P25 is negative (see Table 1). 
the UK in terms of measures that focus on the lower tail of distribution (the 25/50 percentile ratio) but lower for those that focus on the upper tail of the distribution (the 90/50 percentile ratio).

Table 3 presents summary statistics for net financial and net housing wealth as well as for the main subcomponents comprising these assets (total financial assets, total housing assets, financial debt, housing debt, total debt and total gross wealth). We are not able to compute net financial and net housing wealth for Sweden as it is not possible to separately identify housing debt and financial debt in the Swedish data. As can be seen here in all countries housing equity is the dominant asset in households' portfolios. It accounts for about 85 to 87 per cent of total net worth in Finland and Italy and around 81 per cent of total net worth in the UK. The respective estimate for US households is between 57 and 61 per cent depending on the dataset source (with the PSID providing the upper estimate). House ownership is most prevalent in Italy (at 72 per cent) and least so in Sweden (at just 58 per cent). Italy also exhibits the highest levels of housing equity at all points of the distribution (reflecting mainly that Italian household hold very little housing debt). The second highest levels of housing equity at lower points of the distribution is observed in the UK whereas at higher percentile points in the US, although P90 housing equity in the UK falls between US(SCF) and US(PSID) estimates.

Although financial wealth accounts for a smaller share of total household net worth in all countries, cross-country differences in net financial wealth are striking. The US stands out as the country with the highest average levels of net financial wealth with an estimated mean of $€ 90,000$ based on data from SCF and $€ 62,000$ based on PSID. Italy and the UK follow with a mean at around $€ 24,000$ and $€ 22,000$ respectively while Finland ranks at the bottom at around $€ 9,000$. These differences arise mainly from differences at the tails of the distributions. At lower wealth percentiles the US and Finland have the highest absolute levels of negative financial wealth while at the upper tail the US has around twice as high or even higher wealth levels than the UK (which is the country with the next highest net financial wealth levels).

Table 4 presents inequality measures for each wealth component. As can be seen here in all countries the distribution of net financial wealth is considerably more skewed than that of net housing wealth. The highest levels of inequality in net financial assets, measured by the Gini coefficient, is observed in Finland (1.39), followed by the US (at 1.02) and the UK (0.99) while Italy ranks at the bottom (at 0.81$)^{4}$. In terms of housing equity inequality Italy ranks again at the bottom as the least unequal country while the US at the top as the most unequal country. It is noteworthy that the distribution of the gross components of these assets is considerably less skewed than the distribution of the corresponding net components. Looking at gross wealth as a total (i.e. defined as the sum of gross financial and non-financial assets) we note that

4 As noted in Cowell, Karagiannaki and McKnight (2012) while the Gini coefficient can be computed across the whole number range, i.e. including zero and negative values, in this case it is not bound by the unit interval as it is when computed over strictly positive values. 
this is especially the case for Sweden where inequality in gross wealth, in terms of Gini coefficient, is more than 0.20 points lower than the inequality in net worth $(0.66$ compared to 0.89 ).

As we mentioned in the introduction our interest in this paper is in understanding the source of cross-country differences in the distribution of wealth and in particular in characterising the contribution of socio-economic differences in explaining differences in the distribution of wealth and observed levels of wealth inequality. We consider five separate factors: 1) age 2) household structure 3) educational attainment 4) working status and 5) household income (net of capital gains and interest rate payments).

To illustrate the main differences across countries in Table 5 we present statistics describing cross-country differences in the distribution of the main household characteristics used in the analysis. The most notable differences, according to the statistics in this table, are the substantially lower proportion of younger aged households in Italy, the lower proportion of older aged households and the higher proportion of lone parent households in the US (in terms of lone parent household the US is followed closely by the UK, Sweden and Finland) and the higher proportion of more educated households in the US and Sweden. As expected, differences in the level and the distribution of household disposable income are striking. The US is the country with the highest mean income levels but also the more dispersed income distribution followed by the UK. On the other end of the spectrum Finland and Sweden have lower average income levels but also substantially lower income inequality. Mean income levels in Italy are similar to that of the two Nordic counties but levels of income inequality similar to the UK.

\section{Methodology}

Following DiNardo, Fortin and Lemieux (1996) we use semi-parametric decomposition methods to estimate the portion of cross-country differences which is attributable to differences in the distribution of household characteristics. ${ }^{5}$ We begin by defining $i=1 \ldots 5$ to be a variable indicating country. Further, let $\mathrm{w}$ denote wealth and $\mathrm{z}$ a vector of wealth determinants. The distribution of wealth for each country $i$ can be thought to be given by:

$5 \quad$ As stressed by Bover (2010) "An advantage of comparing conditional distributions rather than conditional densities is that one avoids the critical issue of choice of smoothing method and the differences in the results that may ensue. This is particularly relevant in the case of wealth (as compared to income), given that there is often a marked spike at zero because a non-negligible proportion of the population has no wealth. Capturing these spikes complicates the estimation of densities and the results often depend on the smoothing method adopted." 


$$
\begin{aligned}
F(w \mid i=1, \ldots, 5) & \\
& =\int_{z} F(w, z \mid i=1, . .5) d z \\
& =\int_{z} F(w \mid z, i=1, \ldots 5) d F_{z}(z \mid i=1, \ldots, 5)
\end{aligned}
$$

The counterfactual distribution of interest can be thought of as the distribution that mixes the distribution of characteristics of one country - let's say country 1 - with the wealth generating function from another country - here country 2.

$$
\begin{array}{r}
F(w \mid i=1) \\
=\int_{z} F(w \mid z, i=2) d F(z \mid i=1)
\end{array}
$$

Following DiNardo, Fortin and Lemieux (DFL, hereafter) equation (2) can be rewritten as:

$$
\begin{gathered}
F(w \mid i=1) \\
=\int_{z} F(w \mid z, i=2) \Psi(\mathrm{z}) d F(z \mid i=2)
\end{gathered}
$$

where $\Psi(\mathrm{z})=\frac{d F(z \mid i=1)}{d F(z \mid i=2)}$ is a reweighting factor. The reweighting factor is simply a function of $\mathrm{z}$ and can be easily estimated using standard methods such as probit or logit.

The basic idea of the DFL approach is to start with one country (let's say country 1) and then replace the distribution of $\mathrm{z}, \mathrm{F}(\mathrm{z} \mid i=1)$, with the distribution of characteristics in country $2(\mathrm{~F}(\mathrm{z} \mid i=2))$ using the reweighting factor $\Psi(\cdot)$ :

$$
\Psi(\mathrm{z})=\frac{\operatorname{Pr}(\mathrm{z} \mid \mathrm{i}=1)}{\operatorname{Pr}(\mathrm{z} \mid \mathrm{i}=2)}=\frac{\operatorname{Pr}(\mathrm{i}=1 \mid \mathrm{z}) / \operatorname{Pr}(\mathrm{i}=2)}{\operatorname{Pr}(\mathrm{i}=2 \mid \mathrm{z}) / \operatorname{Pr}(\mathrm{i}=1)}
$$

This reweighting factor can be easily computed by estimating a probability model for $\operatorname{Pr}(i=2)$ and using the predicted probabilities to compute a value $\widehat{\Psi}(z)$ for each observation. Following DFL we use a flexible probit model to derive the reweighting function $\Psi(\mathrm{z})$. In principle the reweighted function could also be derived using nonparametric specifications (for applications using non-parametric specifications see Barsky et al. 2002; Bover, 2010; Sierminska et al. 2010). However with z including five variables estimating the reweighting function using a non-parametric specification is practically infeasible in our application.

In addition to considering the aggregate compositional effect in our decompositions we also consider the effect of each covariate separately. This analysis allows us to consider the source of the compositional effect. Following Cobb-Clark and Hildebrand (2006) we begin by expressing the distribution of wealth as follows: 


$$
\begin{aligned}
F(w) \equiv F(w \mid i & =1, \ldots, 5) \\
& =\int F(w \mid y, p, e, d, c, i=1, \ldots, 5) \cdot d F(y \mid p, e, d, c, i=1, \ldots, 5) \\
& \cdot d F(p \mid e, d, c, i=1, \ldots, 5) \cdot d F(e \mid d, c, i=1, \ldots, 5) \cdot d F(d \mid c, i=1, \ldots, 5) \\
& \cdot d F(c \mid i=1, \ldots, 5)
\end{aligned}
$$

Equation (5) captures six conditional expectations. The first is the conditional expected wealth function given the wealth determinants (z), the second is the conditional expected income function (y) given working status (p), education (e), household structure (d) and age composition (c) while the third is conditional labour force participation functions. Similarly the fourth and the fifth functions capture the conditional expected education and household structure functions respectively while final terms capture the age composition.

Following the methodology of Cobb-Clark and Hildebrand (2006) we can use equation (5) to define a series of counterfactual wealth distributions. For expositional simplicity let's assume for the moment that we want to compare country 1 and 2 . To make this comparison we can define the wealth distribution that would prevail if country 2 retained its own conditional wealth, working status, educational attainment, household structure and age composition but had the same conditional income functions as country $1 .^{6}$

Specifically

$$
\begin{aligned}
& F^{A}(w) \\
& =\int_{d F(d \mid c, i=2)} F(w \mid y, p, e, d, c, i=2) \cdot d F(y \mid p, e, d, c, i=1) \cdot d F(p \mid e, d, c, i=2) \cdot d F(e \mid d, c, i=2) \\
& \cdot d F(6)
\end{aligned}
$$

Comparing equation (6) with the actual distribution from country 2 we can isolate the effect of differences in conditional income distribution on cross-country differences in wealth. Similarly we can define the counterfactual wealth distribution $\mathrm{F}^{\mathrm{B}}$ that would result if country 2 had the same income and working status distributions as country 1 but retained its own conditional wealth distribution and the distribution of the remaining characteristics. Similarly $\mathrm{F}^{\mathrm{C}}, \mathrm{F}^{\mathrm{D}}$, and $\mathrm{F}^{\mathrm{E}}$ are the counterfactual wealth distribution if in addition to income and working status, country 2 had the same education, household types and age distributions as country 1 respectively.

Based on these counterfactual distributions we can decompose differences in wealth across pairs of countries in the following way:

$6 \quad$ Note that Cobb-Clark and Hildebrand (2006) use the opposite operationalization to define the compositional effect i.e. they define the distribution that would prevail if group 2 (in their case) had retained their income function but had the same conditional wealth, income etc. function as the comparison group. 


$$
\begin{aligned}
& F^{2}-F^{1}=\left[F^{2}(w)-F^{A}(w)\right]+\left[F^{A}(w)-F^{B}(w)\right]+\left[F^{B}(w)-F^{C}(w)\right]+ \\
& {\left[F^{C}(w)-F^{D}(w)\right]+\left[F^{D}(w)-F^{E}(w)\right]+\left[F^{E}(w)-F^{1}(w)\right]}
\end{aligned}
$$

To estimate the counterfactual distributions described in equation (7) we use the reweighting approach proposed by DFL. In our application we reweight the wealth distributions of each of our countries in order for the distribution of characteristics to match that of our comparison country (country 1 ).

$$
\begin{aligned}
& F^{A}(w) \\
& =\int_{y, p, e, d, c} F(w \mid y, p, e, d, c, i=2) \cdot d F(y \mid p, e, d, c, i=2) \cdot d F(p \mid e, d, c, i=2) \\
& \cdot d F(e \mid d, c, i=2) \cdot d F(d \mid c, i=2) \\
& \cdot d F(c \mid i=2)
\end{aligned}
$$

where

$$
\Psi_{y, p, e, d, c, i}=\frac{\operatorname{Pr}(i=1 \mid y, e, p, d, c, i) \cdot P(i=2 \mid e, p, d, c, i)}{\operatorname{Pr}(i=2 \mid y, e, p, d, c, i) \cdot P(i=1 \mid e, p, d, c, i)}
$$

The remaining counterfactuals can be constructed similarly.

As discussed in Cobb-Clark and Hildebrand (2006) - and earlier by DFL - the difficulty with the decomposition as the one described by equation (4) is that the effect attributed to each factor would always depend on the sequence at which its effect is evaluated. Equation (7) describes just one of the many possible sequences. Using 5 components to decompose wealth differences leads to 120 relevant sequences. With no particular preference over the relevant sequence we follow Cobb-Clark and Hildebrand (2006) and calculate each in turn and present results of the simple average across all possible sequences. ${ }^{7}$

In all our decompositions we use the UK as our base country and compare it to each of the remaining four countries. Each of the counterfactual distributions is then constructed by reweighting the distributions of characteristics in each of the countries in order to mirror the distributions of characteristics in the UK. The difference in the observed and the counterfactual distribution in each of the countries captures the contribution of characteristics to the observed differences in net worth. We first implement our decompositions for net worth and then in section 5 we move to implement the decomposition for each of its subcomponents separately considering both differences in the extent of ownership of different types of assets, the degree of indebtedness as well as levels of wealth holdings.

$7 \quad$ Fortin et al. (2010) propose an alternative method for estimating the individual effects. 


\section{Analysing cross-country differences in the distribution of net worth}

\subsection{Cumulative wealth distributions}

Table 6 and Figure 2 show that although differences in characteristics account for some of the observed differences in the distribution of net worth, a significant differences remain unexplained. The exact share of the difference accounted for by characteristics varies across the distribution and across countries. Differences in characteristics can contribute both positively and negatively to explaining the overall observed difference. At some points in the distribution, for some countries, differences in characteristics appear to account for more than $100 \%$ of the difference with the UK. In Figure 2 this can be observed where the reweighted distribution lies above or below the UK and the actual distribution. That is to say that if the distribution characteristics across the distribution of net worth was the same as that observed in the UK the difference in the predicted value of net worth at a particular percentile of the net worth distribution would be even greater than that observed between the actual distributions. Table 6 shows the detail for five points (P10, P25, P50, P90 and P95) in the distributions. For Finland, differences in the distribution of characteristics account for between 28 and more than $600 \%$ of the differential with the UK at these five points with the magnitude of the effect first increasing and then decreasing as we move towards higher wealth percentiles. At the $10^{\text {th }}$ percentile for example characteristics account for about $€ 2,180$ out of the $€ 2,370$ differential (or $92 \%$ of total wealth difference with the UK). At the $25^{\text {th }}$ percentile its contribution increases even further (accounting for more than $600 \%$ of the wealth difference with the UK; i.e. reaching a level higher than that in the UK) but then falls to $28 \%$ at the $95^{\text {th }}$ percentile. Some strong effects are also estimated for the US where the effect of household characteristics operates towards reducing net worth at lower wealth percentiles and towards increasing it at mid and higher wealth percentiles. On the other hand, the characteristics play a very small role in explaining differences in net worth holdings in Sweden relative to the UK, even at the lower end of the distribution where we might expect to find stronger effects. Similarly, household characteristics appear to play a very small role in explaining Italian wealth holdings. If anything the results appear to suggest that the distribution of household characteristics in Italy predict lower net worth at higher wealth percentiles relative to what would have prevailed if the distribution of characteristics was similar to the UK.

Table 7 moves to the next step of the decomposition to attribute the contribution of each set of covariates to the compositional effect at four points in the net worth distributions (P10, P25, P50 and P90). In each panel of the table, the first row shows the total (unadjusted) differences in net worth with the UK, the second row shows the total compositional effect (i.e. the part of the difference which can be explained by differences in the distribution of characteristics) while rows 3-7 divide the compositional effect into the contribution of the five main factors (i.e. income, working status, education, household structure and age). In most countries the greatest differences in the compositional effects in terms of magnitude are accounted for by differences in age, income and household structure distributions of the populations. The exceptions being the US were differences in education are greater than 
differences in household structure and Sweden where educational differences are greater than age for the top half of the wealth distribution. There is some variation across the wealth distributions. Education is greater than age at P90 in the UK-US comparison, working status is greater than household structure or age in the UKFinland comparison and education is greater than household structure at P90 in the UK-Sweden comparison. Also working status at P10 is greater in the UK-Finland and UK-Sweden comparisons than for UK-US or UK-Italy.

In most countries the factor with the largest contribution in the compositional effect is household income. It accounts for much of the lower wealth holdings in Finland (relative to the UK), especially at the lower tail of the distributions and is the dominant factor in explaining the high wealth holdings of the US households in the upper tail of the distribution (PSID; education for SCF). The effect of income differences has been to reduce the observed differences in net worth between Italy and the UK (this means that if Italian households had the same income distribution as the UK net worth holdings would have been even higher). Interestingly income differences explains a very small amount of the differences in net worth between Swedish and UK households. Differences in age distributions also have some important effects, especially in explaining the lower wealth holdings of Finnish households (with the relative effect being stronger in the lower tail of the distribution) and the higher wealth holdings of Italian households. Large cross country variation in the distribution of different family types, also contribute to cross-country differences in household net worth particularly in Sweden (especially in the lower tail) and Italy (median and above). Finally it is worth noting that educational attainment plays some role in explaining the higher wealth holdings in the US and Sweden with the effect in both countries, especially in the US being particularly strong in the upper tail of the distribution.

In summary, despite some important individual effects, household characteristics account for only part of the cross-country variation in household wealth and its distribution. The largest share of the differences remains unexplained pointing towards the importance of country specific effects as the main determinant of crosscountry variation in wealth distributions.

\subsection{Wealth inequality}

In this section we assess the extent to which differences in the distribution of characteristics contribute to cross-country differences in the levels of wealth inequality. Table 8 presents various wealth inequality measures for the actual and counterfactual wealth distributions in each of our five countries. The difference with the UK and the amount of the difference explained by differences in the distribution of characteristics are presented in rows 3 and 4. As can be seen in this table the distribution of characteristics explains a large share of the higher net worth inequality in Finland (relative to the UK). This effect is evident in terms of all inequality measures but is particularly strong for measures that focus on the lower tail of the distribution (i.e. the $25 / 50$ percentile ratio). It is interesting to note that in terms of the counterfactual net worth distribution Finland ranks either second (after Italy) or first 
as the least unequal country (followed by Italy) for the percentile ratio measures and equal first (with Italy) when measured by the Gini coefficient. The opposite is the case in Italy, where the distribution of characteristics appear to have an equalizing effect with respect to net worth inequality in terms of all inequality measures. So, in terms of the counterfactual net worth distribution Italy ranks first or second as the least unequal country in terms of all inequality measures except from the Gini in terms of which Italy and Finland rank equal first. The UK is identified as the third least unequal country followed by the US and Sweden which once again are the most unequal countries.

\section{Analysis by wealth component}

\section{$5.1 \quad$ Levels analysis}

In order to understand better the factors that shape cross-country differences in the distribution of household net worth in this section we analyse cross country differences in the composition and size of different asset holdings. From previous analyses we know that there is substantial variation in the ownership and the levels of different asset and debt holdings both across and within countries (across different demographic groups). In this section we use a counterfactual analysis similar to the one we adopted above to examine the role of household characteristics and country specific factors (proxied by the unexplained country effects) in explaining the variation in the distribution of different wealth components. We use two main measures of wealth: net financial and net non-financial wealth (i.e. principal home equity plus the net value of investment real estates) as well as their main subcomponents - financial assets, housing assets, financial debt and housing debt. Finer disaggregation would be desirable but not feasible given data availability in LWS. Unfortunately for Sweden, we are unable to separately identify financial and housing wealth and therefore we not able to compute net financial wealth or housing equity (although we are still able to examine the gross components of these assets as well as a total debt measure).

Table 9 shows cross-country differences in ownership rates in these two types of assets as well as in three measures of household indebtedness: financial indebtedness, housing indebtedness and any type of indebtedness. Although the size and the direction of the contribution of characteristics vary both across countries and across different asset and debt types a large share of cross-country differences remains unexplained. The contribution of characteristics in explaining differences in asset ownership is rather small. There are two main exceptions however: in Finland and Sweden the distribution of characteristics appears to significantly compress homeownership. Interestingly, the counterfactual homeownership rates, suggest that Finland has the highest homeownership rates. Although counterfactual homeownership rates are higher than the actual, Sweden still has the lowest homeownership rates than any of the other countries. With the exception of the US, and especially PSID, we find a larger variation in the counterfactual financial debt ownership than we do for the actual. In terms of the effects household characteristics 
have on housing debt it is interesting to note that the counterfactual US rates (PSID) are lower than the UK (contrasting to the actual mortgage rates rankings). With the exception of Finland the effect of characteristics in explaining differences in the degree of indebtedness is very small.

Table 10 presents various percentiles of the actual and counterfactual net financial and net housing wealth distributions and their subcomponents (Table A.2 reports results for the conditional distributions). The first panel shows results for net financial wealth and its two components (gross financial wealth and financial debt). Comparing the actual and counterfactual net financial wealth distributions we first can note that the distribution of characteristics make a small contribution in explaining the distribution of net financial assets in Italy. A similar comparison for Finland, shows that financial wealth is higher in the counterfactual than in the actual distribution at all points of the distribution, and especially at the middle and lower tail of the distribution, suggesting that partly the lower net financial wealth holdings in Finland can be explained by household characteristics. Results based on the SCF, suggest that although the distribution of characteristics in the US play no role in explaining the lower wealth levels at the lower wealth percentiles they do explain to some extent the higher wealth holdings in the upper tail of the distribution. Despite differences in the magnitude of the effects, the patterns in PSID are similar. Looking at the two components comprising net financial wealth we see that in all countries the contribution of characteristics are stronger for financial assets than for financial debt, pointing towards the operation of stronger unobserved country effects in the distribution of financial debt. Summarising, the results show that although household characteristics explain some of the observed variation in financial wealth across our five countries, it is predominantly unexplained country effects that drive cross-country differences especially insofar it concerns the distribution of financial debt.

The second panel of Table 10 shows results for housing equity and its subcomponents (gross housing wealth and housing debt). Again the distribution of characteristics makes almost no contribution in explaining the housing wealth and mortgage debt holdings in Italy. In Finland although differences in the distribution of characteristics explain a sizeable proportion of the lower housing equity levels, especially at the middle and the lower tail of the distribution, these effects are largely driven by the impact of characteristics on homeownership probability (see Table 9) and the resulting increase in levels of housing wealth in the lower tail of the distribution. It is worth-noting here that the increase in the counterfactual Finnish housing wealth distribution is not accompanied by a similar increase in housing debt pointing again to the importance of country specific mortgage market conditions. Although the distribution of characteristics appears to explain a larger share of the substantially higher mortgage debt holdings among American households, American households are still found to hold substantially higher mortgage debt than their counterparts in any other country (followed closely by the UK). Despite the decrease in mortgage debt, housing equity in the US falls significantly at all points of the distribution when we reweight household characteristics to match the UK. As it appears American households tend to invest less in housing wealth than either UK or 
Italian households at all points of the distribution and less than Finnish households up to about the $75^{\text {th }}$ percentile (after around the 75 th percentile US housing wealth distribution lies above the Finnish). In Sweden, although the distribution of characteristics explains a significant share of the lower housing wealth holdings - an effect that is associated with their positive impact on homeownership and to a lesser extent on wealth levels - housing wealth in Sweden is still substantially lower than in any other country. In summary, we conclude that although household characteristics play some role in explaining the observed variation in the distribution of housing wealth across our five countries, it is mostly unobserved country effects determined by cultural differences, institutional environment and the functioning of the housing and mortgage markets that drive cross-country differences in housing wealth. Country specific effects are stronger for mortgage debt than for gross housing wealth giving support for the importance of cultural and mortgage market differences in driving cross-country variation in the distribution of housing wealth.

Comparative analysis of net worth, gross wealth (i.e. the sum of financial and housing assets) and total debt (at the bottom panel of Table 10) suggests that differences in the distribution of characteristics in Sweden explain a higher share of differences in gross wealth holdings than they do for debt - a finding which again points to the strong unobserved country effect in the distribution of debt holdings. A similar observation can be made in a varying degree for all countries.

\subsection{Inequality}

In Table 11 we analyse the extent to which cross-country differences in the degree of inequality in the distribution of financial and housing wealth can be explained by differences in the distribution of characteristics (Table A.2 in the appendix reports results for the conditional distributions). Generally the results of this table suggest that the contribution of characteristics in explaining cross-country differences in net financial wealth and net housing wealth inequality is small. Imposing a common distribution of characteristics does not result in any change in the inequality rankings for neither net financial nor net housing wealth. For net financial wealth the most sizeable effects are found for Finland, where the Gini coefficient is reduced by roughly 20 per cent (from 1.39 to 1.14 ) and the top 1 and 10 wealth shares by roughly 65 and 77 per cent respectively when we reweight the distribution of characteristics to resemble the UK. For Italy the results suggest that the distribution of characteristics has a disequalizing effect on net financial wealth inequality in terms of the Gini coefficient but reduce the degree of concentration at the top $1 \%$ of the distribution. In the US their effects depend on the survey used. According to the SCF, the distribution of characteristics have an equalising effect in terms of Gini coefficient but an disequalizing effect in terms of the two concentration measures i.e. the top 1\% and 5\% wealth shares. Results from PSID suggest the opposite for the top $1 \%$.

The effects of household characteristics on housing equity inequality are more sizeable but again their impact on country inequality ranking is small. The distribution of characteristics have an equalizing effect on the distribution of housing equity in Italy but an disequalizing effect in Finland and the US - especially if the SCF is used 
instead of PSID. Again the most sizeable effects are found for Finland. Reweighting the distribution of household characteristics in Finland to resemble the UK reduces the Gini coefficient by about 8 per cent placing Finland at the top as the least unequal country (in contrast to the actual distribution where it was the second least unequal country after Italy). In Italy and the US the compositional effects are rather small and do not result to any significant change in country ranking. In Italy they work toward decreasing housing equity inequality while in the US towards increasing it. Comparisons of the two components comprising housing equity show that although the effects in Finland and Italy are exclusively related to housing assets, in the US sizeable effects are estimated for both housing assets and debts. In Sweden which along with the US is the most unequal country in terms of the distribution of housing assets, the effects of characteristics have a rather small effect in accounting for the higher degree of inequality.

\section{The unexplained country effects}

\subsection{Measurement issues}

As mentioned in the data section despite the substantial ex-post harmonisation process applied to the datasets included in the LWS database there are some important measurement and definitional differences which could not be accounted for and which may affect cross-country comparisons. Part of the unexplained country effect as identified above may reflect these differences.

Although it is not possible to provide an exact estimate of the extent to which the unexplained country effects, as measured in the previous section, reflect definitional and measurement issues, in this section we highlight some issues affecting data comparability and their implications for measured wealth inequality. ${ }^{8} \mathrm{~A}$ feature of the Swedish household survey is that it does not record deposit accounts unless the interest payments from these assets exceed 100 SEK (approximately 10 Euro in 2002). Given that the interest rate was approximately $3.75 \%$ in 2002 this implies that accounts with less than 270 euro were excluded. ${ }^{9}$ This will lead to an underestimate of cash savings in Sweden, most likely affecting the lower end of the distribution. To determine the importance of this restriction we apply a similar bottom coding in the deposit accounts in other countries. Although a small impact at the lower end of the distribution is clear in all countries, its impact on overall net worth inequality is trivial. In the UK for example wealth inequality in terms of the Gini coefficient remains unchanged by the application of bottom coding.

8 A more complete discussion of the differences can be found in Cowell et al. (2012).

9 Approximately 15-20 per cent of total deposits have been excluded (see LWS survey information for Sweden http://www.lisdatacenter.org/our-data/lws-database/bycountry/swedenwealth/ last accessed 19/9/2012) 
Another feature of the Swedish wealth survey is that business debt cannot be disentangled from other components of debt (i.e. housing and financial debt). This means that the measure of net worth for Sweden includes business debt. For all other countries, the measure of net worth that we use in this paper (NW1) does not include business debt as part of households' liabilities. Since business debt in NW1 is not offset by business assets, its inclusion in NW1 by the Swedish wealth survey has an important impact on measured net worth inequality. This can be assessed comparing differences in net worth inequality estimates based on NW1 and NW2. The latter is the LWS measure of net worth which includes business assets and liabilities. Note that the latter measure is available only for a subset of countries (Italy, US and Sweden). Estimates of net worth inequality based on these two measures are reported in the first four columns of Table 12. As can be seen from this table, in all countries but Sweden the inequality of net worth excluding business equity (NW1) is lower than for net worth which includes it (NW2), implying that business equity has a disequalising effect on net worth inequality. The only exception to this rule is Sweden for which net worth including business equity is lower than the measure of net worth which excludes it. This reflects the fact that the former measure (NW1) includes business debt but not business assets.

A further issue which raises concerns about cross-country comparability relates to differences in the definition of household unit adopted in each survey. As mentioned earlier, in most surveys used in our analysis a household is defined as a group of individuals who live together and share expenses. The only exception is the UK which does not adopt the share of expenses restriction in its definition of household unit, which might be expected to lead to a slight underestimation of net worth inequality. In Sweden although the household unit definition is very close to the one adopted in the other surveys, for individuals non-responding to the telephone interview (around 30 per cent), it was not possible to identify cohabiting adults without common children. In this case cohabiting adults are counted as two separate households and only the sample person was included in the survey. This means that in the Swedish survey the number of single person and single parent households is somewhat overestimated (Statistics Sweden, 2006). In our counterfactual analysis we reweight household type distributions to match the UK household type distribution which means we can account for the part of the bias that this causes on family type distribution but not any bias that this causes to the wealth estimates themselves.

\subsection{The role of educational loans}

One component of debt included in the measure of net worth that we use in our analysis is debt resulting from educational loans. Unlike other forms of debt which are usually offset by the value of the asset they were used to fund, educational loans are offset by a future income stream. Since for many households educational loans are a critical step on household wealth accumulation, their inclusion in households' liabilities may be debated. Our analysis of LWS shows that there is considerable cross-country variation both in the size of educational loans and their take-up rates. In Cowell et al. (2012) we discuss in detail the institutional framework related to educational loans for the five counties we analyse and present some interesting 
summary statistics describing their distribution. Here we mention the main crosscountry differences and we discuss their implications on measured wealth inequality.

For the period we analyse, the take-up of student loans in both Italy and the UK were very low. For Finland and Sweden the respective take-up estimates among eligible students stand at around 35 per cent and 65 per cent respectively while for the US results from the National Longitudinal Study of Youth suggest that among young adults ever enrolled in college 46 per cent have educational loans (Dwyer et al., 2012). Matching these aggregate statistics, analysis of LWS suggest that educational loans represent about 11 per cent of overall debt holding in Sweden and around 3 and 5 per cent in Finland and the US respectively. Although educational loan data in LWS is not available for either Italy or the UK, in both countries the role of educational loans in supporting higher education at the time of the surveys was rather limited (although this has been changing rapidly in the UK during the last 10 years). As the statistics in Table 12 suggest, the exclusion of educational loans from net worth (NW1) has an important effect on net worth inequality in Sweden - where the Gini coefficient falls from 0.89 to 0.83 by the exclusion of educational loans - but its effect in both Finland and particularly the US is very small (in Finland the respective Gini coefficients for the measures of net worth which includes and excludes educational loans are 0.68 to 0.67 respectively while in the US the Gini falls from 0.83 to 0.82 ). The Gini coefficients of the counterfactual net worth distribution which exclude educational loans are significantly lower and educational loans explain all of the higher inequality in Sweden relative to the US. When we use the estimate of net worth which includes business equity and debt explicitly (NW2) actual and counterfactual inequality is higher in the US than in Sweden when educational loans are excluded.

\section{Conclusions}

One might have supposed that that there would be higher wealth inequality in countries characterised by higher income inequality; but this is not true for the countries studied here. Although unequal income is related to unequal ability to save and accumulate assets, other factors prove to be more important in shaping the distribution of wealth.

The differences between countries' wealth distributions cannot be explained away by differences in age, working status, household structure, education and income. But, taking these factors into account, some wealth inequality comparisons turn out as one might have expected. For example, the US is unambiguously more unequal than the UK which is more unequal than Italy. By contrast the position of Finland in the ranking - between the UK and Italy - may come as a surprise. But perhaps the greatest surprise is the very high level of wealth inequality in Sweden (highest in terms of the Gini coefficient, second in terms of top 1\%, top 5\%, top $10 \%$ and P90/P50). 
The high level of wealth inequality in Sweden may be affected by survey definitions (household definition which results in too many single headed households) and the inclusion of business debt. However, in interpreting the high relative level of wealth inequality it should be noted that average gross wealth is lowest in Sweden as is P50 and P25; P90 is second lowest behind Finland. Taken together this suggests that wealth holdings are relatively low among Swedish households and what wealth is held is unequally distributed. There are good reasons for this. Home ownership is lower in Sweden and in terms of thinking about the large unexplained component of our computed cross-country differences the need to hold assets in Sweden is greatly reduced by state provision of health, education, pensions and income during periods of hardship. For many years the Swedish population has saved in the form of higher taxation and therefore private wealth holdings are likely to be less representative of Swedish households' quality of life (from a financial perspective) than say for US households. Since the 1990s changes to the Swedish welfare state have meant that Swedish households are increasingly expected to make their own provisions and this may mean that inequalities in private household wealth holdings may become increasingly important in determining people's standard of living.

Two main components of net worth are particularly important.

Housing is the largest asset that most households will ever hold. Homeownership rates are similar across four of the five countries at around $70 \%$ but Sweden stands out as having relatively low rates at 57\% (2002). Housing supply in Sweden is relatively constrained in the large urban areas where there is high demand and the Swedish housing system is quite complex and idiosyncratic. Around one-third of owner occupied homes (effectively all owner occupied apartments) are in what is known as the tenant-owned co-operative sector which appears to create a number of market distortions (European Housing Review, 2011). Also the recently abolished wealth tax and a higher average property tax rate (Hilbers et al., 2008) may have created some disincentives to acquire and accumulate housing assets. Italy also stands out with much higher rates of outright homeownerships (62\%), explained partly by cultural differences (later age of household formation, greater parental assistance with house purchase, multi-generational households, attitudes to debt) and institutional differences (access to credit). This contributes to positive and relatively high rates of net worth among Italian households particularly in the lower and middle parts of the net worth distributions.

Debt holdings give rise to much of the wealth inequality differences across countries. Italy has lower financial debt as well as housing debt. The fact that the Swedish data additionally include household-held business debt contributes to the higher debt holding found in Sweden. American households are the most likely to hold financial and housing debt and the average value of these debts is greater. In addition, debtholding is comparatively more common in later life (Cowell et al., 2012). We have shown cross country differences in educational loans both in their incidence and their average value; explaining all of the difference in wealth inequality between the US 
and Sweden. Cultural and institutional differences in relation to debt holdings result in greater unobserved country effects than for other wealth components. 


\section{References}

Barsky, R., Bound, J., Charles, K. K. and J. P. Lupton (2002) "Accounting for the Black-White Wealth Gap: A Nonparametric Approach" Journal of the American Statistical Association, American Statistical Association, vol. 97, pages 663-673, September.

Bover, O. (2010) "Wealth inequality and Household Structure" Review of Income and Wealth, vol. 52: 2.

Ball, M. (2011) 2011 RICS European Housing Review, RICS Royal Institution of Chartered Surveyors, Brussels.

Cobb-Clark, D.A. and V. Hildebrand (2006) "The Wealth of Mexican Americans" The Journal of Human Resources, vol. XLI:4.

Cowell, F. A., Karagiannaki, E. and A. McKnight (2012) "Mapping and Measuring the distribution of household wealth: A cross-country analysis" CASEpaper 165, CASE, London School of Economics and Political Science, London

DiNardo, J., Fortin, N. M. and T. Lemieux (1996) "Labour Market Institutions and the Distribution of Wages, 1973-1992: A Semiparametric Approach" Econometrica, Vol. 64:5

Dwyer, R.E., McCloud, L. and R. Hodson (2012) "Debt and Graduation from American Universities" Social Forces doi: 10.1093/sf/sos072

Fortin, N. M., Lemieux, T. and S. Firpo (2010) "Decomposition methods in Economics" NBER Working Paper: 16045

Hilbers, P., Hoffmaister, A. W., Banerji, A. and H. Shi (2008) "House Price Developments in Europe: A Comparison", IMF Working Paper WP/08/211.

Jäntti, M., Sierminska, E. and T. M. Smeeding (2008). The joint distribution of household income and wealth: Evidence from the Luxembourg Wealth Study. OECD Social, Employment and Migration Working Paper 65, OECD, Paris.

Sierminska, E., Brandolini, A. and T.M. Smeeding (2006) "The Luxemburg Wealth Study - A cross-country comparable database for household wealth research" Journal of Economic Inequality, 2006:4 pp. 375-383

Sierminska, E., Brandolini, A. and T. M. Smeeding (2006) "Comparing Wealth Distribution across Rich Countries: First Results from the Luxembourg Wealth Study" Luxemburg Wealth Study Working Paper no. 1

Sierminska, E., Brandolini, A. and Smeeding, T. M. (2008) "Comparing Wealth Distribution across Rich Countries: First Results from the Luxembourg Wealth Study" (June 16, 2008). Bank of Italy Research Paper No. A7

Sierminska, E., Frick, J. R. and Grabka, M. (2010) "Examining the Gender Wealth Gap in Germany" Oxford Economic Papers, vol. 62: pp. 669-690

Statistics Sweden, 2006, Facts about wealth statistics, http://www.scb.se/statistik/HE/HE0104/_dokument/Faktastat2004\%20eng.doc 
Table 1: Mean and various percentiles of household net worth ${ }^{1}$ by country, thousands 2005 Euros $^{2}$

\begin{tabular}{lrrrrrrr}
\hline \hline & \multicolumn{1}{c}{ Mean } & Median & P10 & P25 & P75 & P90 & N \\
\cline { 2 - 7 } NW1 & & & & & & & \\
UK & 116.7 & 62.3 & -0.3 & 2.2 & 150.0 & 302.7 & 3988 \\
Finland & 66.5 & 41.0 & -2.7 & 0.7 & 89.4 & 159.7 & 3893 \\
Italy & 163.6 & 104.0 & 0.0 & 15.9 & 212.2 & 369.2 & 8010 \\
US SCF & 207.0 & 42.4 & -6.3 & 0.3 & 155.6 & 418.4 & 4442 \\
US PSID & 158.1 & 40.9 & -3.9 & 0.2 & 150.0 & 368.1 & 5550 \\
Sweden & 50.9 & 15.9 & -13.1 & -0.7 & 69.9 & 151.5 & 17819 \\
\hline \hline
\end{tabular}

Notes: (1) Net worth (NW1) equal to the sum of net financial assets (TFA1) and housing equity (TNF1). Net financial assets equal to total financial assets (TFA1) minus financial debt - non-housing debt (NHD) in LWS wording. Housing equity equals to the sum of own principal residence, investment real estate (TNF1) minus mortgage debt. (2) All monetary values are expressed in 2005 Euros (Euro $16 \mathrm{ppp}$ ).

Source: Own calculations based on LWS database.

Table 2: Gini and GE(2) for household total net worth (NW1) by country

\begin{tabular}{|c|c|c|c|c|}
\hline & Gini & $\mathrm{GE}(2)$ & $\mathrm{P} 90 / \mathrm{P} 50$ & $\mathrm{P} 25 / \mathrm{P} 50$ \\
\hline \multicolumn{5}{|l|}{ NW1 } \\
\hline UK & 0.66 & 1.18 & 4.86 & 0.04 \\
\hline Finland & 0.68 & 1.61 & 3.90 & 0.02 \\
\hline Italy & 0.60 & 1.16 & 3.55 & 0.15 \\
\hline US SCF & 0.83 & 15.23 & 9.88 & 0.01 \\
\hline US PSID & 0.80 & 10.07 & 9.00 & 0.00 \\
\hline Sweden & 0.89 & 5.30 & 9.51 & na \\
\hline
\end{tabular}

Note: Net worth (NW1) equal to the sum of net financial assets (TFA1) and housing equity (TNF1). Net financial assets equal to total financial assets (TFA1) minus financial debt - non-housing debt (NHD) in LWS wording. Housing equity equals to the sum of own principal residence, investment real estate (TNF1) minus mortgage debt. All monetary values are expressed in 2005 Euros (Euro 16 ppp).

Source: Own calculations based on LWS database. 
Table 3: Mean and various percentiles of household net worth components by country and year, thousands 2005 Euros

\begin{tabular}{|c|c|c|c|c|c|c|c|c|c|}
\hline & \multicolumn{4}{|c|}{ All } & \multirow[b]{2}{*}{$\%$ non-zero } & \multicolumn{4}{|c|}{ Owners } \\
\hline & Mean & P50 & $\mathrm{P} 25$ & P90 & & Mean & P50 & $\mathrm{P} 25$ & P90 \\
\hline \multicolumn{10}{|c|}{ Net financial wealth } \\
\hline UK & 21.9 & 1.9 & 0.0 & 63.6 & 0.88 & 25.0 & 4.2 & -0.4 & 72.2 \\
\hline Finland & 8.8 & 1.3 & -0.5 & 27.0 & 0.95 & 9.3 & 1.6 & -0.8 & 28.3 \\
\hline Italy & 24.2 & 6.4 & 0.7 & 51.5 & 0.83 & 29.3 & 9.7 & 3.2 & 58.6 \\
\hline US SCF 2001 & 90.0 & 1.0 & -4.3 & 150.7 & 0.95 & 94.9 & 1.6 & -5.0 & 158.3 \\
\hline US PSID 2001 & 62.1 & 1.5 & -1.0 & 121.7 & 0.88 & 70.3 & 2.9 & -2.1 & 144.1 \\
\hline Sweden & n.a. & n.a. & n.a. & n.a. & n.a. & n.a. & n.a. & n.a. & n.a. \\
\hline \multicolumn{10}{|c|}{ Net housing wealth } \\
\hline UK & 94.8 & 54.9 & 0.0 & 245.6 & 0.70 & 136.3 & 92.4 & 49.1 & 288.9 \\
\hline Finland & 57.6 & 37.1 & 0.0 & 137.2 & 0.69 & 83.8 & 61.3 & 35.5 & 163.0 \\
\hline Italy & 139.4 & 92.8 & 0.0 & 318.2 & 0.73 & 192.0 & 133.1 & 79.6 & 376.6 \\
\hline US SCF 2001 & 117.1 & 35.1 & 0.0 & 255.8 & 0.69 & 169.4 & 77.1 & 31.2 & 325.8 \\
\hline US PSID 2001 & 96.0 & 33.1 & 0.0 & 228.9 & 0.66 & 146.3 & 77.9 & 34.1 & 292.2 \\
\hline Sweden & n.a. & n.a. & n.a. & n.a. & n.a. & n.a. & n.a. & n.a. & n.a. \\
\hline \multicolumn{10}{|c|}{ Gross financial assets } \\
\hline UK & 25.5 & 4.2 & 0.1 & 66.4 & 0.80 & 31.7 & 8.3 & 1.4 & 82.3 \\
\hline Finland & 12.8 & 2.7 & 0.3 & 28.6 & 0.92 & 13.9 & 3.2 & 0.6 & 30.9 \\
\hline Italy & 25.1 & 7.1 & 1.6 & 52.1 & 0.81 & 31.0 & 10.6 & 4.2 & 60.6 \\
\hline US SCF & 99.9 & 5.8 & 0.9 & 156.0 & 0.92 & 109.2 & 7.4 & 1.5 & 169.5 \\
\hline US PSID & 68.4 & 3.9 & 0.4 & 126.6 & 0.83 & 82.0 & 7.8 & 1.6 & 152.9 \\
\hline Sweden & 22.0 & 4.7 & 0.1 & 53.1 & 0.79 & 27.9 & 9.0 & 2.3 & 63.4 \\
\hline \multicolumn{10}{|c|}{ Gross housing assets } \\
\hline UK & 122.3 & 86.7 & 0.0 & 288.9 & 0.70 & 175.1 & 130.0 & 82.3 & 332.2 \\
\hline Finland & 66.2 & 48.4 & 0.0 & 151.7 & 0.68 & 96.9 & 72.6 & 48.4 & 177.6 \\
\hline Italy & 143.5 & 95.5 & 0.0 & 318.2 & 0.72 & 198.2 & 142.1 & 84.9 & 384.0 \\
\hline US SCF & 163.6 & 77.9 & 0.0 & 340.9 & 0.69 & 235.7 & 126.6 & 73.0 & 425.6 \\
\hline US PSID & 134.7 & 77.9 & 0.0 & 303.9 & 0.66 & 203.9 & 132.5 & 77.9 & 375.0 \\
\hline Sweden & 56.3 & 19.4 & 0.0 & 149.4 & 0.58 & 97.9 & 68.9 & 35.8 & 196.0 \\
\hline \multicolumn{10}{|l|}{ Financial debt } \\
\hline UK & 3.5 & 0.0 & 0.0 & 11.6 & 0.46 & 7.7 & 3.6 & 0.8 & 19.1 \\
\hline Finland & 4.0 & 0.0 & 0.0 & 9.7 & 0.38 & 10.4 & 4.8 & 1.9 & 21.0 \\
\hline Italy & 0.9 & 0.0 & 0.0 & 1.6 & 0.12 & 7.6 & 5.3 & 2.6 & 15.9 \\
\hline US SCF & 10.0 & 1.8 & 0.0 & 25.3 & 0.65 & 15.3 & 7.9 & 2.0 & 31.2 \\
\hline US PSID & 6.3 & 0.06 & 0.0 & 14.6 & 0.50 & 12.6 & 4.9 & 2.0 & 27.3 \\
\hline Sweden & n.a. & n.a. & n.a. & n.a. & n.a. & n.a. & n.a. & n.a. & n.a. \\
\hline \multicolumn{10}{|l|}{ Housing debt } \\
\hline UK & 27.6 & 0.0 & 0.0 & 86.7 & 0.40 & 69.8 & 57.8 & 36.1 & 124.2 \\
\hline Finland & 8.5 & 0.0 & 0.0 & 32.3 & 0.28 & 30.1 & 24.2 & 10.5 & 63.9 \\
\hline Italy & 3.8 & 0.0 & 0.0 & 1.4 & 0.10 & 36.7 & 26.5 & 9.5 & 79.6 \\
\hline US SCF & 46.5 & 0.0 & 0.0 & 126.6 & 0.47 & 100.1 & 71.6 & 34.1 & 188.0 \\
\hline US PSID & 38.7 & 0.0 & 0.0 & 124.7 & 0.44 & 88.6 & 70.1 & 39.0 & 175.3 \\
\hline Sweden & n.a. & n.a. & n.a. & n.a. & n.a. & n.a. & n.a. & n.a. & n.a. \\
\hline \multicolumn{10}{|c|}{ Total gross wealth } \\
\hline UK & 147.8 & 101.1 & 6.1 & 346.7 & 0.89 & 165.7 & 115.6 & 54.3 & 364.5 \\
\hline Finland & 79.0 & 56.6 & 3.1 & 173.5 & 0.96 & 82.3 & 59.7 & 6.5 & 176.0 \\
\hline Italy & 168.6 & 106.9 & 18.0 & 376.6 & 0.92 & 183.3 & 118.5 & 43.0 & 397.8 \\
\hline US SCF & 263.5 & 93.0 & 6.6 & 513.7 & 0.94 & 281.4 & 102.1 & 19.6 & 537.6 \\
\hline US PSID & 203.1 & 93.0 & 2.9 & 445.1 & 0.90 & 226.2 & 114.4 & 18.5 & 472.4 \\
\hline Sweden & 78.3 & 36.8 & 2.0 & 192.0 & 0.84 & 92.8 & 55.4 & 11.7 & 209.4 \\
\hline \multicolumn{10}{|l|}{ Total debt } \\
\hline UK & 31.1 & 1.4 & 0.0 & 96.8 & 0.60 & 52.3 & 39.1 & 5.1 & 118.3 \\
\hline Finland & 12.5 & 0.7 & 0.0 & 40.4 & 0.52 & 24.0 & 12.9 & 4.3 & 59.4 \\
\hline Italy & 4.7 & 0.0 & 0.0 & 9.6 & 0.20 & 23.3 & 9.5 & 4.2 & 63.6 \\
\hline US SCF & 56.5 & 14.6 & 0.1 & 143.9 & 0.76 & 74.5 & 38.0 & 7.8 & 163.6 \\
\hline US PSID & 45.0 & 9.7 & 0.0 & 132.5 & 0.68 & 66.4 & 42.9 & 7.8 & 159.7 \\
\hline Sweden & 27.5 & 7.8 & 0.0 & 75.6 & 0.71 & 38.9 & 20.0 & 6.2 & 91.3 \\
\hline
\end{tabular}


Table 4: Inequality measures for different wealth components

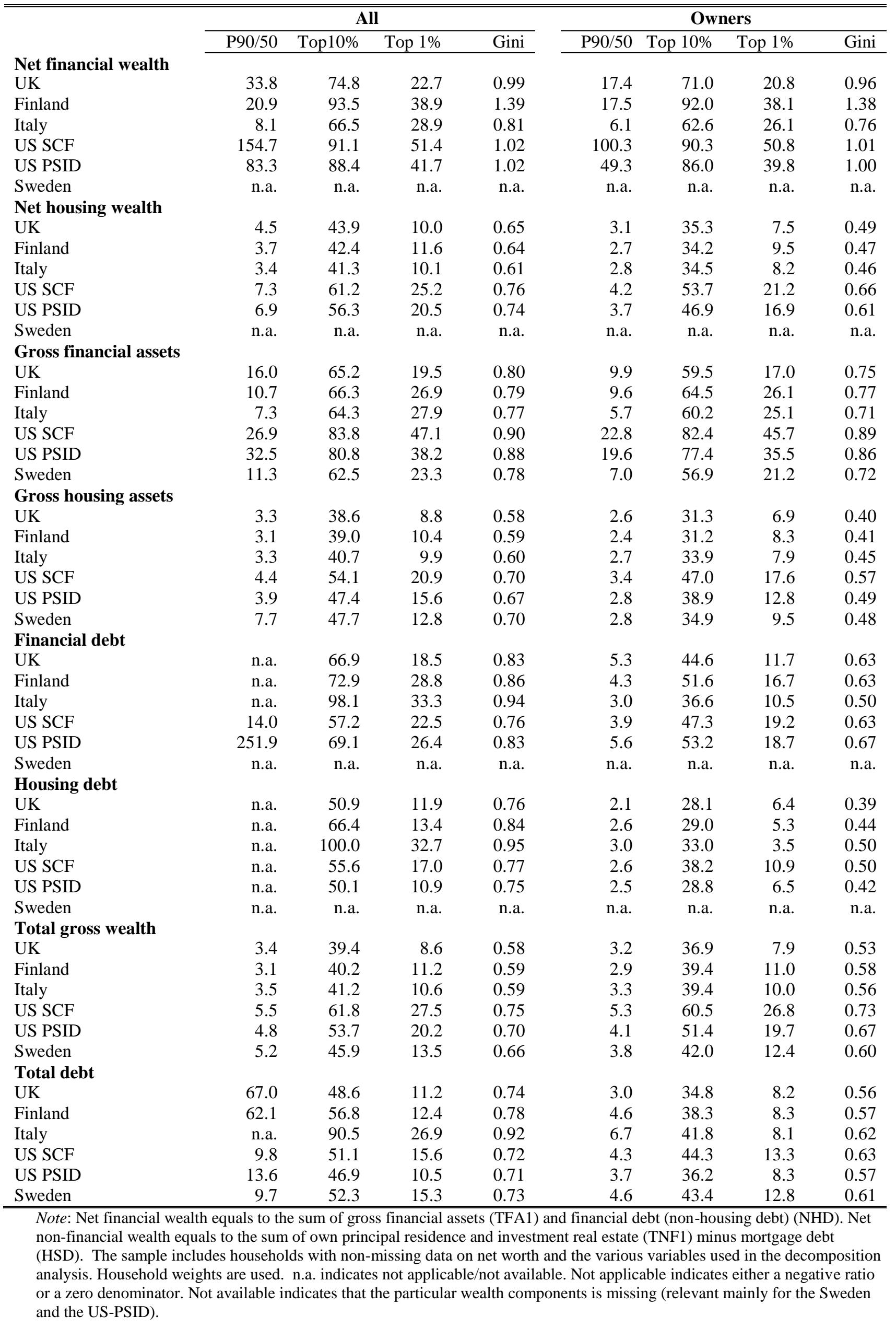


Table 5: Cross-country differences in the distribution of various demographic characteristics

\begin{tabular}{|c|c|c|c|c|c|c|}
\hline & UK & Finland & Italy & US SCF & US PSID & Sweden \\
\hline \multicolumn{7}{|l|}{ Age of household head } \\
\hline $16-24$ & 3.83 & 7.26 & 0.68 & 5.59 & 5.25 & 6.61 \\
\hline $25-34$ & 14.29 & 16.70 & 9.40 & 17.14 & 18.63 & 16.91 \\
\hline $35-44$ & 19.29 & 19.97 & 21.47 & 22.31 & 22.16 & 17.73 \\
\hline $45-54$ & 17.37 & 21.00 & 18.80 & 20.61 & 22.40 & 17.51 \\
\hline $55-64$ & 14.89 & 13.81 & 16.90 & 13.24 & 12.55 & 16.57 \\
\hline $65-74$ & 14.02 & 11.73 & 18.21 & 10.77 & 10.92 & 10.87 \\
\hline $75-84$ & 12.01 & 7.70 & 11.66 & 8.31 & 6.32 & 9.72 \\
\hline $85+$ & 4.29 & 1.82 & 2.88 & 2.03 & 1.79 & 4.07 \\
\hline \multicolumn{7}{|l|}{ Household type } \\
\hline Single no children & 30.13 & 38.99 & 23.29 & 28.61 & 33.04 & 48.06 \\
\hline Single with children & 7.50 & 4.79 & 1.31 & 9.93 & 8.11 & 5.57 \\
\hline Single with other adults & 8.90 & 4.37 & 9.66 & 1.74 & 5.18 & 2.21 \\
\hline Couple no children & 25.02 & 25.67 & 20.35 & 30.16 & 23.11 & 23.11 \\
\hline Couple with children & 20.42 & 21.88 & 26.45 & 26.78 & 25.06 & 17.82 \\
\hline Couple with other adults & 8.02 & 4.30 & 18.94 & 2.78 & 5.50 & 3.23 \\
\hline \multicolumn{7}{|c|}{ Working status of household head } \\
\hline Working & 54.17 & 58.00 & 49.09 & 72.31 & 70.55 & 65.61 \\
\hline Unemployed-inactive & 14.29 & 11.94 & 10.35 & 9.73 & 10.65 & 5.80 \\
\hline Retired & 31.55 & 30.07 & 40.56 & 17.96 & 18.8 & 28.58 \\
\hline \multicolumn{7}{|c|}{ Educational attainment of household head } \\
\hline Low & 52.04 & 37.91 & 36.19 & 47.71 & 48.34 & 22.71 \\
\hline Mid & 35.64 & 49.81 & 55.80 & 22.76 & 22.65 & 54.03 \\
\hline High & 12.33 & 12.28 & 8.01 & 29.54 & 29.00 & 23.26 \\
\hline \multicolumn{7}{|l|}{ Home-ownership status } \\
\hline$\%$ of homeowners & 70.15 & 68.30 & 72.22 & 69.42 & 65.38 & 57.24 \\
\hline \multicolumn{7}{|c|}{ Income } \\
\hline \multicolumn{7}{|c|}{ Mean income by income quartile group } \\
\hline Bottom & 6,533 & 6,875 & 5,942 & 7,301 & 9,326 & 7,571 \\
\hline $2^{\text {nd }}$ & 12,147 & 10,864 & 10,438 & 14,928 & 19,403 & 12,199 \\
\hline $3^{\text {rd }}$ & 17,730 & 14,685 & 15,240 & 24,101 & 29,174 & 16,651 \\
\hline Top & 31,641 & 22,330 & 27,597 & 59,638 & 60,647 & 25,617 \\
\hline Mean & 17,025 & 13,511 & 14,739 & 25,644 & 29,343 & 15,420 \\
\hline Median & 14,651 & 12,709 & 12,495 & 18,617 & 24,045 & 14,225 \\
\hline Gini & 0.34 & 0.27 & 0.33 & 0.49 & 0.41 & 0.27 \\
\hline $\begin{array}{l}\text { Number of household with } \\
\text { data on wealth }\end{array}$ & 4,185 & 3,893 & 8,010 & 4,442 & 5,834 & 17,953 \\
\hline
\end{tabular}

Note: The sample includes households with non-zero weight with non-missing information on net worth. Sample size may differ for different variables because of missing values. Household weights are used. The Swedish survey does not record education for persons older than 75 years old. 
Table 6: DFL decomposition of the distribution of net worth (figures in thousands of 2005 Euros)

\begin{tabular}{|c|c|c|c|c|c|}
\hline & P10 & $\mathbf{P 2 5}$ & P50 & P90 & P95 \\
\hline \multicolumn{6}{|l|}{ UK } \\
\hline Actual & -0.29 & 2.24 & 62.26 & 302.65 & 439.86 \\
\hline \multicolumn{6}{|l|}{ Finland } \\
\hline Actual & -2.66 & 0.73 & 40.99 & 159.66 & 222.78 \\
\hline Counterfactual & -0.48 & 9.90 & 59.93 & 210.21 & 284.13 \\
\hline Difference with the UK & -2.37 & -1.51 & -21.27 & -142.99 & -217.08 \\
\hline Explained by characteristics & -2.18 & -9.17 & -18.94 & -50.55 & -61.35 \\
\hline \multicolumn{6}{|l|}{ Italy } \\
\hline Actual & 0.00 & 15.91 & 103.96 & 369.15 & 533.36 \\
\hline Counterfactual & 0.26 & 12.73 & 98.97 & 376.07 & 554.79 \\
\hline Difference with the UK & 0.29 & 13.67 & 41.70 & 66.51 & 93.51 \\
\hline Explained by characteristics & -0.27 & 3.18 & 4.99 & -6.91 & -21.43 \\
\hline \multicolumn{6}{|l|}{ US SCF } \\
\hline Actual & -6.30 & 0.27 & 42.37 & 418.40 & 700.45 \\
\hline Counterfactual & -6.17 & 0.11 & 31.98 & 312.68 & 505.58 \\
\hline Difference with the UK & -6.01 & -1.97 & -19.89 & 115.76 & 260.59 \\
\hline Explained by characteristics & -0.13 & 0.16 & 10.38 & 105.72 & 194.86 \\
\hline \multicolumn{6}{|l|}{ US PSID } \\
\hline Actual & -3.90 & 0.19 & 40.90 & 368.14 & 613.57 \\
\hline Counterfactual & -3.41 & 0.00 & 28.24 & 302.79 & 516.18 \\
\hline Difference with the UK & -3.61 & -2.04 & -21.35 & 65.49 & 173.71 \\
\hline Explained by characteristics & -0.49 & 0.19 & 12.66 & 65.35 & 97.39 \\
\hline \multicolumn{6}{|l|}{ Sweden } \\
\hline Actual & -13.12 & -0.69 & 15.92 & 151.46 & 215.28 \\
\hline Counterfactual & -12.72 & -0.09 & 24.33 & 175.65 & 255.69 \\
\hline Difference with the UK & -12.83 & -2.93 & -46.34 & -151.19 & -224.57 \\
\hline Explained by characteristics & -0.40 & -0.60 & -8.41 & -24.20 & -40.40 \\
\hline
\end{tabular}

Note: Counterfactual distributional statistics are estimated using the DFL decomposition re-weighting procedure. The explanatory variables included in the reweighting function include age education and working status of the household head, household structure, and household income net of capital gains and interest payments. All counterfactual distributions are estimated using UK as a base country i.e. they represent the distribution that would prevail in each of the countries if the distribution of characteristics was similar to the UK. The sample includes households with non-missing data on wealth and in any of the variables used to estimate weighting function. 
Table 7: Detailed decompositions: Differences in selected percentiles of net worth distribution (figures in thousand 2005 Euros)

\begin{tabular}{|c|c|c|c|c|c|c|c|c|c|c|c|c|}
\hline \multirow[b]{2}{*}{ UK-Finland } & \multicolumn{3}{|c|}{ P10 } & \multicolumn{3}{|c|}{ P25 } & \multicolumn{3}{|c|}{ P50 } & \multicolumn{3}{|c|}{ P90 } \\
\hline & bs & & se & bs & & se & bs & & se & bs & & se \\
\hline Unadjusted difference & -2.4 & **** & 0.3 & -1.5 & * & 0.8 & -21.3 & *** & 3.4 & -143.0 & *** & 10.4 \\
\hline Compositional effect & -2.2 & **** & 0.4 & -9.2 & ** & 3.2 & -18.9 & *** & 3.6 & -50.5 & *** & 11.7 \\
\hline Income & -1.1 & **** & 0.2 & -4.4 & ** & 1.4 & -10.9 & *** & 1.8 & -34.0 & **** & 6.8 \\
\hline Working status & 0.2 & & 0.1 & -0.1 & & 0.3 & -0.2 & & 0.5 & -7.9 & ** & 2.9 \\
\hline Education & -0.2 & * & 0.1 & -0.3 & & 0.3 & -0.2 & & 0.5 & -0.1 & & 2.3 \\
\hline Household structure & 0.0 & & 0.1 & -1.8 & * & 0.9 & -3.9 & ** & 1.3 & -6.6 & * & 2.7 \\
\hline Age & -1.0 & **** & 0.2 & -2.5 & ** & 0.9 & -3.7 & *** & 1.0 & -1.9 & & 2.0 \\
\hline \multicolumn{13}{|l|}{ UK-Italy } \\
\hline Unadjusted difference & 0.3 & & 0.3 & 13.7 & $* * *$ & 2.0 & 41.7 & *** & 3.2 & 66.5 & *** & 13.1 \\
\hline Compositional effect & -0.3 & & 0.3 & 3.2 & & 2.1 & 5.0 & & 4.0 & -6.9 & & 13.3 \\
\hline Income & -1.0 & $* * *$ & 0.2 & -7.7 & **** & 1.5 & -15.3 & *** & 1.8 & -54.2 & *** & 9.4 \\
\hline Working status & 0.0 & & 0.0 & 0.8 & $*$ & 0.3 & 0.4 & & 0.6 & -5.9 & & 3.4 \\
\hline Education & 0.1 & & 0.1 & 1.3 & & 0.8 & 6.0 & *** & 1.4 & 16.1 & ** & 6.2 \\
\hline Household structure & 0.3 & ** & 0.1 & 4.1 & $* * *$ & 0.9 & 7.5 & $* * *$ & 1.6 & 19.8 & **** & 5.2 \\
\hline Age & 0.3 & $*$ & 0.1 & 4.6 & *** & 1.2 & 6.3 & *** & 1.6 & 17.4 & *** & 4.0 \\
\hline \multicolumn{13}{|l|}{ UK-US SCF } \\
\hline Unadjusted difference & -6.0 & $* * *$ & 0.6 & -2.0 & ** & 0.7 & -19.9 & *** & 3.5 & 115.8 & *** & 16.0 \\
\hline Compositional effect & -0.1 & & 0.5 & 0.2 & & 0.1 & 10.4 & *** & 2.5 & 105.7 & *** & 22.7 \\
\hline Income & 1.0 & $* * *$ & 0.2 & 0.2 & * & 0.1 & 8.5 & $* * *$ & 1.0 & 54.7 & **** & 9.9 \\
\hline Working status & -0.2 & & 0.2 & 0.1 & & 0.0 & 0.0 & & 0.8 & -9.9 & & 6.9 \\
\hline Education & 0.6 & * & 0.3 & 0.2 & $* *$ & 0.1 & 8.4 & *** & 1.3 & 67.6 & **** & 12.7 \\
\hline Household structure & 0.1 & & 0.4 & 0.1 & & 0.1 & 3.1 & $*$ & 1.5 & 30.5 & **** & 8.9 \\
\hline Age & -1.6 & *** & 0.3 & -0.4 & * & 0.2 & -9.5 & *** & 1.2 & -37.1 & **** & 6.1 \\
\hline \multicolumn{13}{|l|}{ UK-US PSID } \\
\hline Unadjusted difference & -3.6 & $* * *$ & 0.6 & -2.0 & ** & 0.7 & -21.4 & $* * *$ & 3.4 & 65.5 & **** & 18.5 \\
\hline Compositional effect & -0.5 & & 0.5 & 0.2 & & 0.1 & 12.7 & **** & 2.7 & 65.4 & ** & 20.3 \\
\hline Income & 1.3 & *** & 0.3 & 0.4 & *** & 0.1 & 19.2 & *** & 1.8 & 59.0 & *** & 10.9 \\
\hline Working status & -0.2 & & 0.1 & 0.0 & & 0.0 & -0.1 & & 0.5 & -3.7 & & 3.2 \\
\hline Education & -0.3 & & 0.2 & 0.1 & * & 0.0 & 4.7 & $* * *$ & 1.0 & 44.2 & **** & 7.7 \\
\hline Household structure & 0.0 & & 0.1 & 0.0 & & 0.0 & -0.9 & & 1.0 & 2.3 & & 4.0 \\
\hline Age & -1.3 & *** & 0.3 & -0.3 & **** & 0.1 & -10.2 & *** & 1.7 & -36.4 & *** & 9.1 \\
\hline \multicolumn{13}{|l|}{ UK-Sweden } \\
\hline Unadjusted difference & -12.8 & $* * *$ & 0.5 & -2.9 & **** & 0.7 & -46.3 & *** & 2.3 & -151.2 & **** & 10.4 \\
\hline Compositional effect & -0.4 & & 0.7 & -0.6 & ** & 0.2 & -8.4 & *** & 1.4 & -24.2 & **** & 3.6 \\
\hline Income & -0.7 & $* *$ & 0.2 & -0.5 & $* * *$ & 0.1 & -5.7 & *** & 0.5 & -22.1 & *** & 2.2 \\
\hline Working status & 0.7 & $* *$ & 0.2 & 0.5 & *** & 0.1 & 2.0 & *** & 0.3 & 1.3 & ** & 0.4 \\
\hline Education & -0.6 & $* *$ & 0.2 & 0.1 & & 0.1 & 3.2 & **** & 0.4 & 13.6 & **** & 1.3 \\
\hline Household structure & 0.8 & $* *$ & 0.3 & -0.2 & $*$ & 0.1 & -5.0 & *** & 0.5 & -13.1 & **** & 1.4 \\
\hline Age & -0.6 & $* *$ & 0.2 & -0.5 & $* * *$ & 0.1 & -2.9 & $* * *$ & 0.5 & -3.9 & **** & 1.0 \\
\hline
\end{tabular}

Note: Counterfactual distributional statistics are estimated using the DFL decomposition re-weighting procedure. The explanatory variables included in the reweighting function include age education and working status of the household head, household structure, and household income net of capital gains and interest payments. All counterfactual distributions are estimated using UK as a base country i.e. they represent the distribution that would prevail in each of the countries if the distribution of characteristics was similar to the UK. The sample includes households with non-missing data on wealth and in any of the variables used to estimate the weighting function. Standard errors based on 50 replications. 
Table 8: DFL decomposition of net worth inequality

\begin{tabular}{|c|c|c|c|c|c|c|}
\hline & P90/50 & $\mathbf{P} 25 / 50$ & Gini & $\begin{array}{r}\text { Top } \\
10 \% \\
\end{array}$ & Top 5\% & Top $1 \%$ \\
\hline \multicolumn{7}{|l|}{ UK } \\
\hline Actual & 4.86 & 0.04 & 0.66 & 45.36 & 29.83 & 9.98 \\
\hline \multicolumn{7}{|l|}{ Finland } \\
\hline Actual & 3.90 & 0.02 & 0.68 & 45.34 & 31.19 & 13.03 \\
\hline Counterfactual & 3.51 & 0.17 & 0.62 & 41.20 & 28.05 & 11.28 \\
\hline Difference with the UK & -0.96 & -0.02 & 0.02 & -0.02 & 1.36 & 3.05 \\
\hline Explained by characteristics & 0.39 & -0.15 & 0.06 & 4.14 & 3.14 & 1.75 \\
\hline \multicolumn{7}{|l|}{ Italy } \\
\hline Actual & 3.55 & 0.15 & 0.60 & 42.07 & 28.64 & 10.76 \\
\hline Counterfactual & 3.80 & 0.13 & 0.62 & 43.88 & 29.70 & 11.58 \\
\hline Difference with the UK & -1.31 & 0.11 & -0.06 & -3.29 & -1.19 & 0.78 \\
\hline Explained by characteristics & -0.25 & 0.02 & -0.02 & -1.81 & -1.06 & -0.82 \\
\hline \multicolumn{7}{|l|}{ US SCF } \\
\hline Actual & 9.88 & 0.01 & 0.83 & 70.30 & 57.31 & 32.68 \\
\hline Counterfactual & 9.78 & 0.00 & 0.81 & 64.40 & 49.75 & 27.26 \\
\hline Difference with the UK & 5.02 & -0.03 & 0.17 & 24.94 & 27.48 & 22.70 \\
\hline Explained by characteristics & 0.10 & 0.01 & 0.02 & 5.90 & 7.56 & 5.42 \\
\hline \multicolumn{7}{|l|}{ US PSID } \\
\hline Actual & 9.00 & 0.00 & 0.80 & 63.47 & 48.61 & 25.24 \\
\hline Counterfactual & 10.72 & 0.00 & 0.81 & 64.27 & 49.42 & 25.94 \\
\hline Difference with the UK & 4.14 & -0.04 & 0.14 & 18.11 & 18.78 & 15.26 \\
\hline Explained by characteristics & -1.72 & 0.00 & -0.01 & -0.80 & -0.81 & -0.70 \\
\hline \multicolumn{7}{|l|}{ Sweden } \\
\hline Actual & 9.51 & -0.04 & 0.89 & 58.10 & 40.53 & 17.52 \\
\hline Counterfactual & 7.22 & 0.00 & 0.85 & 56.04 & 40.10 & 17.77 \\
\hline Difference with the UK & 4.65 & -0.08 & 0.23 & 12.74 & 10.70 & 7.54 \\
\hline Explained by characteristics & 2.29 & -0.04 & 0.04 & 2.06 & 0.43 & -0.25 \\
\hline
\end{tabular}

Note: Counterfactual distributional statistics are estimated using the DFL decomposition re-weighting procedure. The explanatory variables included in the reweighting function include age education and working status of the household head, household structure, and household income net of capital gains and interest payments. All counterfactual distributions are estimated using UK as a base country i.e. they represent the distribution that would prevail in each of the countries if the distribution of characteristics was similar to the UK. The sample includes households with nonmissing data on wealth and in any of the variables used to estimate weighting function. 
Table 9: DFL decomposition of difference in in asset and debt ownership and the extent of different types of indebtedness

\begin{tabular}{|c|c|c|c|c|c|c|c|c|}
\hline & $\begin{array}{r}\text { Financial } \\
\text { assets } \\
\end{array}$ & $\begin{array}{r}\text { Housing } \\
\text { assets } \\
\end{array}$ & $\begin{array}{r}\text { Financial } \\
\text { debt }\end{array}$ & $\begin{array}{r}\text { Housing } \\
\text { debt }\end{array}$ & Debt & NW $1<0$ & $\mathrm{NFA}<0$ & THSE $<0$ \\
\hline \multicolumn{9}{|l|}{ UK } \\
\hline Actual & 0.803 & 0.699 & 0.462 & 0.395 & 0.595 & 0.117 & 0.252 & 0.003 \\
\hline \multicolumn{9}{|l|}{ Finland } \\
\hline Actual & 0.923 & 0.683 & 0.383 & 0.283 & 0.521 & 0.150 & 0.268 & 0.018 \\
\hline Counterfactual & 0.931 & 0.768 & 0.339 & 0.295 & 0.497 & 0.105 & 0.221 & 0.013 \\
\hline \multicolumn{9}{|l|}{ Italy } \\
\hline Actual & 0.812 & 0.722 & 0.120 & 0.102 & 0.199 & 0.027 & 0.054 & 0.007 \\
\hline Counterfactual & 0.826 & 0.693 & 0.118 & 0.103 & 0.199 & 0.024 & 0.042 & 0.006 \\
\hline \multicolumn{9}{|l|}{ US SCF } \\
\hline Actual & 0.915 & 0.694 & 0.651 & 0.465 & 0.758 & 0.192 & 0.378 & 0.009 \\
\hline Counterfactual & 0.907 & 0.674 & 0.634 & 0.379 & 0.708 & 0.195 & 0.401 & 0.009 \\
\hline \multicolumn{9}{|l|}{ US PSID } \\
\hline Actual & 0.834 & 0.660 & 0.501 & 0.437 & 0.678 & 0.154 & 0.287 & 0.006 \\
\hline Counterfactual & 0.775 & 0.622 & 0.442 & 0.311 & 0.574 & 0.160 & 0.276 & 0.007 \\
\hline \multicolumn{9}{|l|}{ Sweden } \\
\hline Actual & 0.789 & 0.575 & n.a. & n.a. & 0.706 & 0.274 & n.a. & n.a. \\
\hline Counterfactual & 0.794 & 0.621 & n.a. & n.a. & 0.716 & 0.256 & n.a. & n.a. \\
\hline
\end{tabular}

Note: Counterfactual distributional statistics are estimated using the DFL decomposition re-weighting procedure. The explanatory variables included in the reweighting function include age education and working status of the household head, household structure, and household income net of capital gains and interest payments. All counterfactual distributions are estimated using UK as a base country i.e. they represent the distribution that would prevail in each of the countries if the distribution of characteristics was similar to the UK. The sample includes households with nonmissing data on wealth and in any of the variables used to estimate weighing function. 
Table 10: DFL decompositions of cross country differences in the distribution of different wealth components (thousand 2005 euros)

\begin{tabular}{|c|c|c|c|c|c|c|c|c|c|}
\hline \multirow[b]{2}{*}{ UK } & \multicolumn{3}{|c|}{ Net financial wealth } & \multicolumn{3}{|c|}{ Gross financial wealth } & \multicolumn{3}{|c|}{ Financial debt } \\
\hline & $\mathrm{P} 25$ & P50 & P90 & $\mathrm{P} 25$ & P50 & P90 & $\mathrm{P} 25$ & P50 & P90 \\
\hline Actual & -0.04 & 1.88 & 63.56 & 0.07 & 4.16 & 66.45 & 0.00 & 0.00 & 11.56 \\
\hline \multicolumn{10}{|l|}{ Finland } \\
\hline Actual & -0.48 & 1.29 & 27.02 & 0.32 & 2.67 & 28.58 & 0.00 & 0.00 & 9.69 \\
\hline Counterfactual & 0.00 & 2.66 & 38.50 & 0.65 & 4.36 & 40.94 & 0.00 & 0.00 & 9.69 \\
\hline \multicolumn{10}{|l|}{ Italy } \\
\hline Actual & 0.74 & 6.36 & 51.45 & 1.59 & 7.11 & 51.98 & 0.00 & 0.00 & 1.59 \\
\hline Counterfactual & 1.17 & 7.10 & 52.12 & 1.82 & 7.43 & 53.04 & 0.00 & 0.00 & 1.33 \\
\hline \multicolumn{10}{|l|}{ US SCF } \\
\hline Actual & -4.30 & 0.97 & 150.67 & 0.94 & 5.80 & 155.95 & 0.00 & 1.80 & 25.28 \\
\hline Counterfactual & -5.11 & 0.34 & 99.34 & 0.55 & 3.51 & 102.08 & 0.00 & 1.17 & 23.18 \\
\hline \multicolumn{10}{|l|}{ US PSID } \\
\hline Actual & -0.97 & 1.46 & 121.74 & 0.39 & 3.90 & 126.61 & 0.00 & 0.06 & 14.61 \\
\hline Counterfactual & -0.49 & 0.39 & 97.39 & 0.04 & 1.95 & 100.31 & 0.00 & 0.00 & 11.69 \\
\hline \multicolumn{10}{|l|}{ Sweden } \\
\hline Actual & - & - & - & 0.14 & 4.69 & 53.12 & - & - & - \\
\hline \multirow[t]{2}{*}{ Counterfactual } & - & - & - & 0.23 & 6.39 & 68.18 & - & - & - \\
\hline & \multicolumn{3}{|c|}{ Net housing wealth } & \multicolumn{3}{|c|}{ Gross housing wealth } & \multicolumn{3}{|c|}{ Housing debt } \\
\hline $\mathbf{U K}$ & $\mathrm{P} 25$ & P50 & P90 & $\mathrm{P} 25$ & P50 & P90 & P25 & P50 & P90 \\
\hline Actual & 0.00 & 54.89 & 245.57 & 0.00 & 86.67 & 288.90 & 0.00 & 0.00 & 86.67 \\
\hline \multicolumn{10}{|l|}{ Finland } \\
\hline Actual & 0.00 & 37.13 & 137.22 & 0.00 & 48.43 & 151.75 & 0.00 & 0.00 & 32.29 \\
\hline Counterfactual & 6.46 & 51.82 & 177.58 & 16.14 & 64.57 & 193.72 & 0.00 & 0.00 & 37.13 \\
\hline \multicolumn{10}{|l|}{ Italy } \\
\hline Actual & 0.00 & 92.82 & 318.24 & 0.00 & 95.47 & 318.24 & 0.00 & 0.00 & 1.38 \\
\hline Counterfactual & 0.00 & 84.86 & 318.24 & 0.00 & 90.17 & 319.30 & 0.00 & 0.00 & 2.12 \\
\hline \multicolumn{10}{|l|}{ US SCF } \\
\hline Actual & 0.00 & 35.06 & 255.75 & 0.00 & 77.91 & 340.87 & 0.00 & 0.00 & 126.61 \\
\hline Counterfactual & 0.00 & 29.22 & 194.79 & 0.00 & 66.81 & 251.27 & 0.00 & 0.00 & 93.50 \\
\hline \multicolumn{10}{|l|}{ US PSID } \\
\hline Actual & 0.00 & 33.11 & 228.87 & 0.00 & 77.91 & 303.86 & 0.00 & 0.00 & 124.66 \\
\hline Counterfactual & 0.00 & 23.37 & 194.79 & 0.00 & 53.57 & 243.48 & 0.00 & 0.00 & 77.91 \\
\hline Sweden & & & & & & & & & \\
\hline Actual & - & - & - & 0.00 & 19.39 & 149.43 & - & - & - \\
\hline Counterfactual & - & - & - & 0.00 & 32.43 & 175.04 & - & - & - \\
\hline & & Net wor & & & ross wea & & & Total d & \\
\hline UK & $\mathrm{P} 25$ & P50 & P90 & $\mathrm{P} 25$ & P50 & P90 & $\mathrm{P} 25$ & P50 & P90 \\
\hline Actual & 2.24 & 62.26 & 302.65 & 6.07 & 101.12 & 346.68 & 0.00 & 1.45 & 96.78 \\
\hline Finland & & & & & & & & & \\
\hline Actual & 0.73 & 40.99 & 159.66 & 3.10 & 56.65 & 173.54 & 0.00 & 0.65 & 40.36 \\
\hline Counterfactual & 9.90 & 59.93 & 210.21 & 19.81 & 72.65 & 217.49 & 0.00 & 0.00 & 46.99 \\
\hline Italy & & & & & & & & & \\
\hline Actual & 15.91 & 103.96 & 369.15 & 18.03 & 106.77 & 376.07 & 0.00 & 0.00 & 9.55 \\
\hline Counterfactual & 12.73 & 98.97 & 376.07 & 13.79 & 103.59 & 388.57 & 0.00 & 0.00 & 10.18 \\
\hline US SCF & & & & & & & & & \\
\hline Actual & 0.27 & 42.37 & 418.40 & 6.62 & 93.01 & 513.74 & 0.08 & 14.61 & 143.85 \\
\hline Counterfactual & 0.11 & 31.98 & 312.68 & 4.28 & 76.45 & 354.86 & 0.00 & 6.95 & 112.14 \\
\hline US PSID & & & & & & & & & \\
\hline Actual & 0.19 & 40.90 & 368.14 & 2.92 & 93.01 & 445.08 & 0.00 & 9.74 & 132.45 \\
\hline Counterfactual & 0.00 & 28.24 & 302.79 & 0.97 & 64.77 & 353.05 & 0.00 & 0.97 & 87.65 \\
\hline Sweden & & & & & & & & & \\
\hline Actual & -0.69 & 15.92 & 151.46 & 2.01 & 36.79 & 191.97 & 0.00 & 7.80 & 75.58 \\
\hline Counterfactual & -0.09 & 24.33 & 175.65 & 2.95 & 52.09 & 226.66 & 0.00 & 9.33 & 87.16 \\
\hline
\end{tabular}


Table 11: DFL decompositions of cross country differences in inequality of different wealth components

\begin{tabular}{|c|c|c|c|c|c|c|c|c|c|}
\hline \multirow[b]{2}{*}{ UK } & \multicolumn{3}{|c|}{ Net financial wealth } & \multicolumn{3}{|c|}{ Gross financial wealth } & \multicolumn{3}{|c|}{ Financial debt } \\
\hline & Top $10 \%$ & Top $1 \%$ & Gini & Top $10 \%$ & Top $1 \%$ & Gini & Top $10 \%$ & Top $1 \%$ & Gini \\
\hline Actual & 74.80 & 22.68 & 0.99 & 65.18 & 19.54 & 0.80 & 66.93 & 18.45 & 0.83 \\
\hline \multicolumn{10}{|l|}{ Finland } \\
\hline Actual & 93.50 & 38.88 & 1.39 & 66.35 & 26.93 & 0.79 & 72.88 & 28.83 & 0.86 \\
\hline Counterfactual & 76.76 & 27.17 & 1.14 & 60.09 & 20.54 & 0.75 & 75.65 & 28.28 & 0.87 \\
\hline \multicolumn{10}{|l|}{ Italy } \\
\hline Actual & 66.53 & 28.93 & 0.81 & 64.34 & 27.89 & 0.77 & 98.11 & 33.27 & 0.94 \\
\hline Counterfactual & 65.98 & 29.21 & 0.79 & 64.09 & 28.25 & 0.76 & 97.96 & 34.59 & 0.94 \\
\hline \multicolumn{10}{|l|}{ US SCF } \\
\hline Actual & 91.12 & 51.38 & 1.02 & 83.76 & 47.14 & 0.90 & 57.15 & 22.53 & 0.76 \\
\hline Counterfactual & 93.08 & 44.35 & 1.08 & 81.32 & 38.68 & 0.88 & 53.97 & 14.58 & 0.75 \\
\hline \multicolumn{10}{|l|}{ US PSID } \\
\hline Actual & 88.43 & 41.65 & 1.02 & 80.77 & 38.21 & 0.88 & 69.07 & 26.37 & 0.83 \\
\hline Counterfactual & 91.30 & 45.40 & 1.02 & 85.11 & 42.15 & 0.91 & 72.24 & 25.74 & 0.85 \\
\hline \multicolumn{10}{|l|}{ Sweden } \\
\hline Actual & - & - & - & 62.47 & 23.29 & 0.78 & - & - & - \\
\hline \multirow[t]{2}{*}{ Counterfactual } & - & - & - & 62.62 & 24.17 & 0.81 & - & - & - \\
\hline & \multicolumn{3}{|c|}{ Net housing wealth } & \multicolumn{3}{|c|}{ Gross housing wealth } & \multicolumn{3}{|c|}{ Housing debt } \\
\hline UK & Top 10\% & Top 1\% & Gini & Top $10 \%$ & Top $1 \%$ & Gini & Top 10\% & Top 1\% & Gini \\
\hline Actual & 43.85 & 9.95 & 0.65 & 38.59 & 8.77 & 0.58 & 50.87 & 11.90 & 0.76 \\
\hline \multicolumn{10}{|l|}{ Finland } \\
\hline Actual & 42.42 & 11.59 & 0.64 & 39.02 & 10.35 & 0.59 & 66.39 & 13.43 & 0.84 \\
\hline Counterfactual & 39.96 & 10.92 & 0.59 & 37.23 & 9.67 & 0.55 & 73.38 & 13.59 & 0.83 \\
\hline \multicolumn{10}{|l|}{ Italy } \\
\hline Actual & 41.28 & 10.09 & 0.61 & 40.70 & 9.93 & 0.60 & 99.95 & 32.29 & 0.95 \\
\hline Counterfactual & 43.12 & 10.33 & 0.63 & 42.45 & 10.11 & 0.62 & 99.90 & 27.76 & 0.95 \\
\hline \multicolumn{10}{|l|}{ US SCF } \\
\hline Actual & 61.22 & 25.17 & 0.76 & 54.12 & 20.94 & 0.70 & 55.61 & 17.01 & 0.77 \\
\hline Counterfactual & 55.45 & 21.02 & 0.73 & 48.64 & 17.49 & 0.67 & 57.11 & 14.65 & 0.80 \\
\hline \multicolumn{10}{|l|}{ US PSID } \\
\hline Actual & 56.27 & 20.54 & 0.74 & 47.43 & 15.61 & 0.67 & 50.09 & 10.89 & 0.75 \\
\hline Counterfactual & 54.09 & 17.80 & 0.74 & 47.51 & 14.35 & 0.68 & 60.41 & 11.47 & 0.81 \\
\hline Sweden & & & & & & & & & \\
\hline Actual & - & - & - & 47.73 & 12.78 & 0.70 & - & - & - \\
\hline Counterfactual & - & - & - & 46.83 & 13.76 & 0.68 & - & - & - \\
\hline & & Net worth & & Tota & gross weal & & & tal debt & \\
\hline UK & Top $10 \%$ & Top $1 \%$ & Gini & Top $10 \%$ & Top 1\% & Gini & Top 10\% & Top 1\% & Gini \\
\hline Actual & 45.36 & 9.98 & 0.66 & 39.39 & 8.60 & 0.58 & 48.63 & 10.93 & 0.74 \\
\hline Finland & & & & & & & & & \\
\hline Actual & 45.34 & 13.03 & 0.68 & 40.24 & 11.22 & 0.59 & 56.80 & 12.42 & 0.78 \\
\hline Counterfactual & 41.20 & 11.28 & 0.62 & 37.82 & 9.93 & 0.55 & 64.14 & 12.62 & 0.77 \\
\hline Italy & & & & & & & & & \\
\hline Actual & 42.07 & 10.76 & 0.60 & 41.33 & 10.60 & 0.59 & 90.47 & 26.90 & 0.92 \\
\hline Counterfactual & 43.88 & 11.58 & 0.62 & 43.06 & 11.18 & 0.61 & 91.51 & 24.07 & 0.92 \\
\hline US SCF & & & & & & & & & \\
\hline Actual & 70.30 & 32.68 & 0.83 & 61.78 & 27.53 & 0.75 & 51.06 & 15.63 & 0.72 \\
\hline Counterfactual & 64.40 & 27.26 & 0.81 & 55.22 & 22.80 & 0.71 & 50.65 & 12.74 & 0.73 \\
\hline US PSID & & & & & & & & & \\
\hline Actual & 63.47 & 25.24 & 0.80 & 53.73 & 20.22 & 0.70 & 46.88 & 10.51 & 0.71 \\
\hline Counterfactual & 64.27 & 25.94 & 0.81 & 56.49 & 22.27 & 0.73 & 53.48 & 10.76 & 0.77 \\
\hline Sweden & & & & & & & & & \\
\hline Actual & 58.10 & 17.52 & 0.89 & 45.91 & 13.46 & 0.66 & 52.27 & 15.26 & 0.73 \\
\hline Counterfactual & 56.04 & 17.77 & 0.85 & 45.81 & 14.38 & 0.65 & 53.48 & 16.35 & 0.73 \\
\hline
\end{tabular}


Table 12: Actual and counterfactual inequality measures for NW1 and NW2 and the role of educational loans

\begin{tabular}{|c|c|c|c|c|c|c|c|c|}
\hline & \multicolumn{2}{|c|}{ NW1 } & \multicolumn{2}{|c|}{ NW2 } & \multicolumn{2}{|c|}{$\begin{array}{c}\text { NW1 } \\
\text { Excluding } \\
\text { educational } \\
\text { loans }\end{array}$} & \multicolumn{2}{|c|}{$\begin{array}{c}\text { NW 2 } \\
\text { Excluding } \\
\text { educational loans }\end{array}$} \\
\hline & Gini & Top 1\% & Gini & Top 1\% & Gini & Top 1\% & Gini & Top 1\% \\
\hline \multicolumn{9}{|l|}{ UK } \\
\hline Actual & 0.66 & 9.98 & n.a. & n.a. & n.a. & n.a. & n.a. & n.a. \\
\hline \multicolumn{9}{|l|}{ Finland } \\
\hline Actual & 0.68 & 13.03 & n.a. & n.a. & 0.67 & 12.92 & n.a. & n.a. \\
\hline Counterfactual & 0.61 & 11.28 & n.a. & n.a. & 0.61 & 11.22 & n.a. & n.a. \\
\hline \multicolumn{9}{|l|}{ Italy } \\
\hline Actual & 0.60 & 10.76 & 0.62 & 12.26 & n.a. & n.a. & n.a. & n.a. \\
\hline Counterfactual & 0.62 & 11.57 & 0.64 & 12.14 & n.a. & n.a. & n.a. & n.a. \\
\hline \multicolumn{9}{|l|}{ US SCF } \\
\hline Actual & 0.83 & 32.68 & 0.85 & 37.46 & 0.82 & 32.43 & 0.85 & 37.25 \\
\hline Counterfactual & 0.81 & 27.39 & 0.82 & 30.46 & 0.80 & 27.02 & 0.81 & 29.99 \\
\hline \multicolumn{9}{|l|}{ US PSID } \\
\hline Actual & 0.80 & 25.24 & 0.82 & 30.33 & n.a. & n.a. & n.a. & n.a. \\
\hline Counterfactual & 0.81 & 26.04 & 0.81 & 27.07 & n.a. & n.a. & n.a. & n.a. \\
\hline \multicolumn{9}{|l|}{ Sweden } \\
\hline Actual & 0.89 & 17.52 & 0.86 & 17.34 & 0.83 & 16.57 & 0.80 & 16.53 \\
\hline Counterfactual & 0.85 & 17.77 & 0.82 & 17.31 & 0.80 & 17.12 & 0.79 & 16.76 \\
\hline
\end{tabular}


Figure 1: Cross country differences in net worth distributions

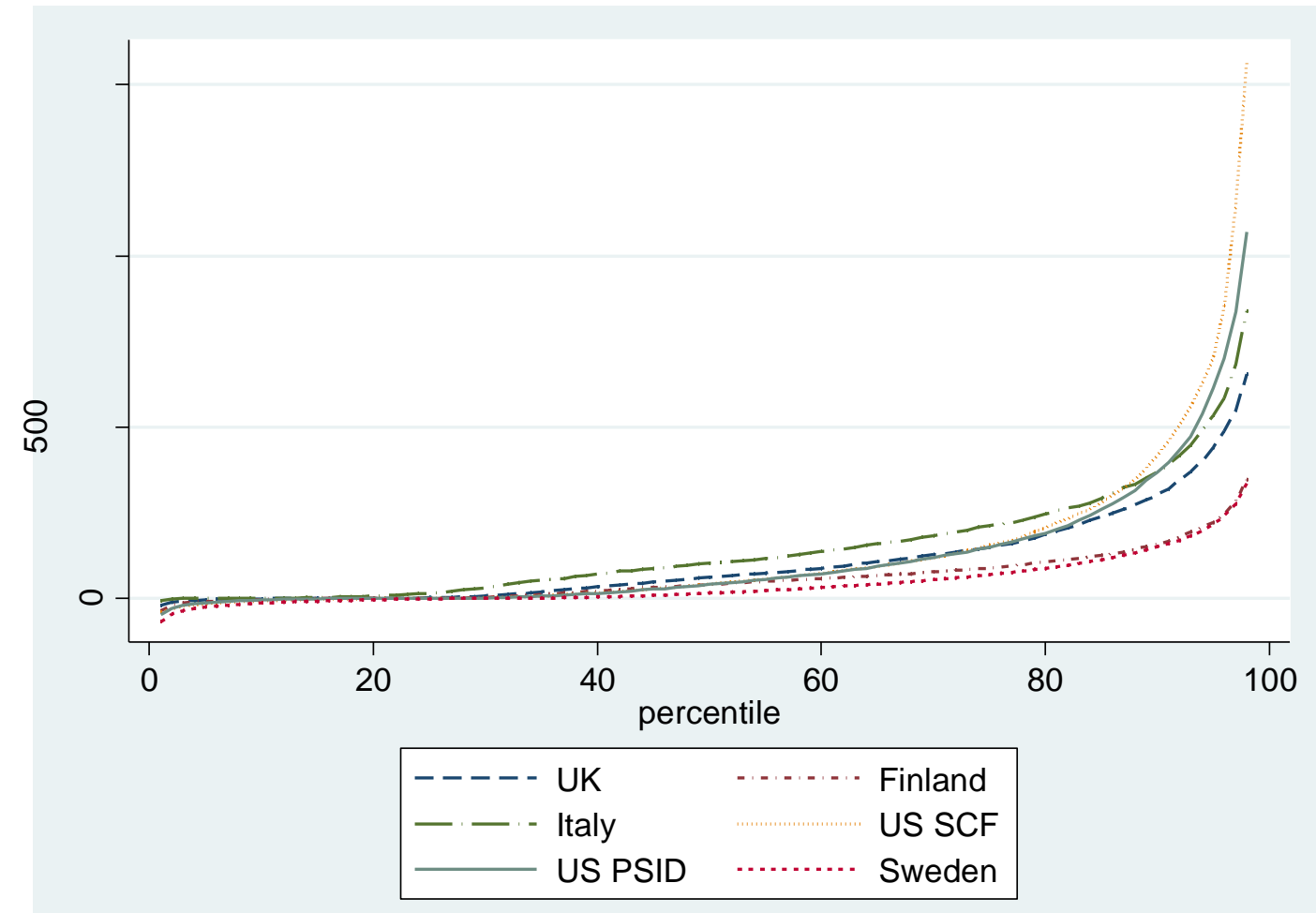

Note: The figure reflects wealth up to the $98^{\text {th }}$ percentile. 
Figure 2: Actual and counterfactual net worth distribution

UK- Finland

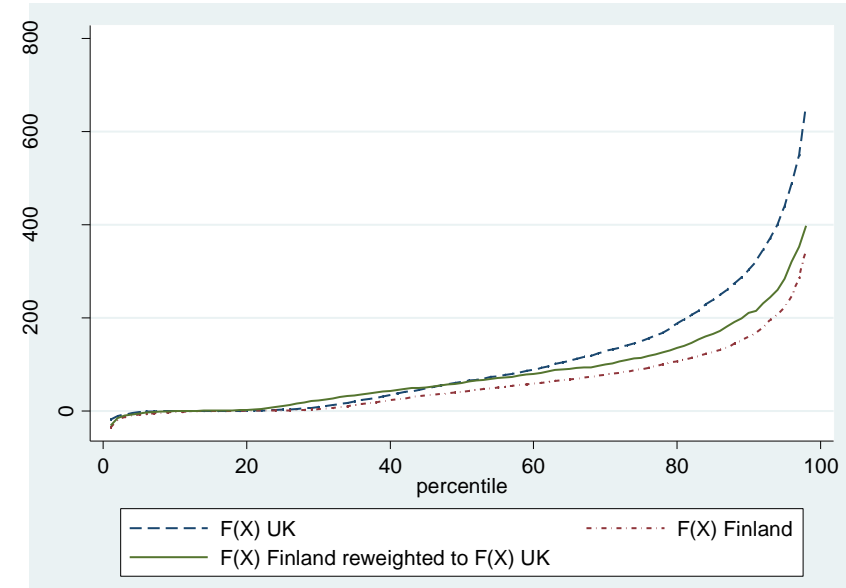

UK-US SCF

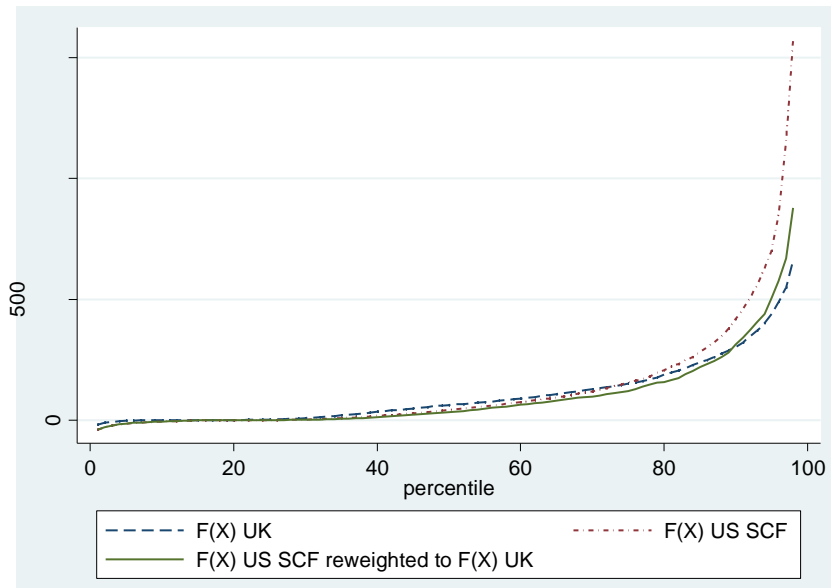

\section{UK-Sweden}

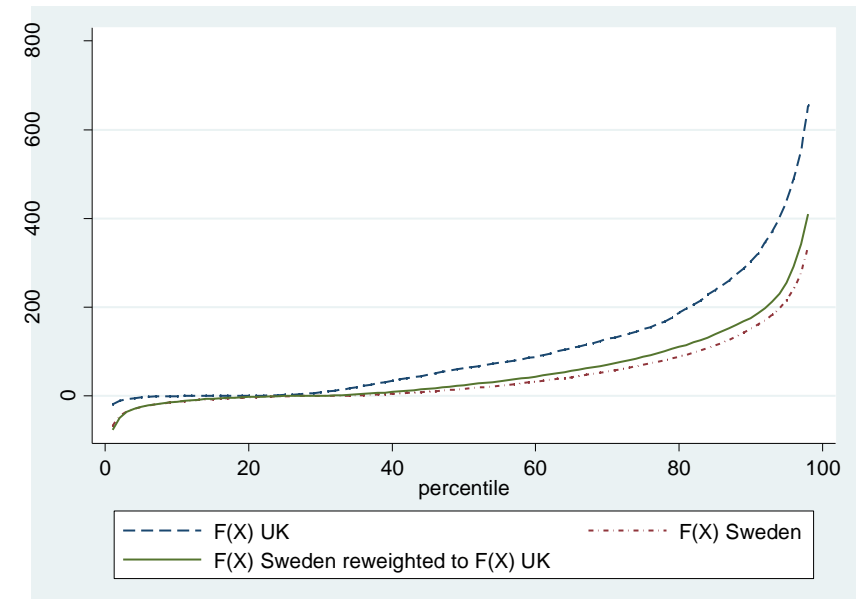

UK-Italy

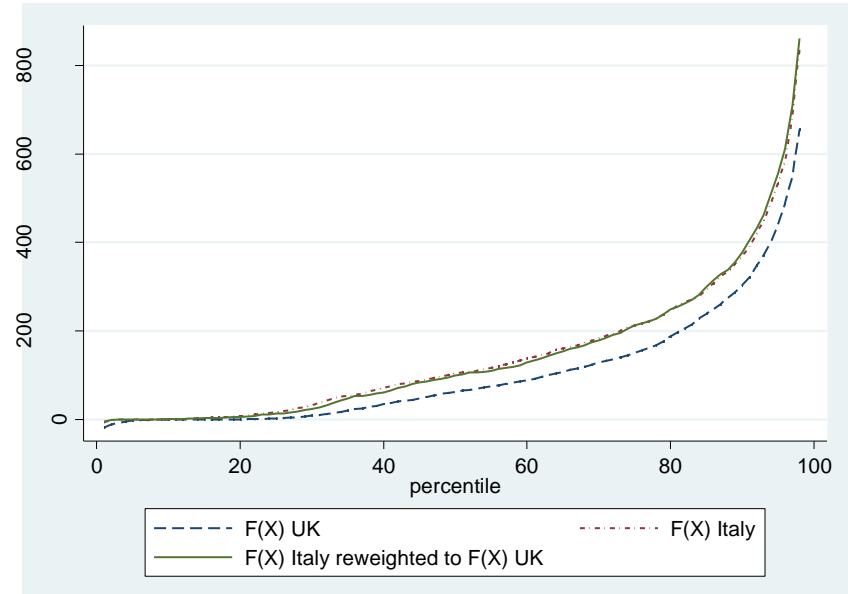

UK-US PSID

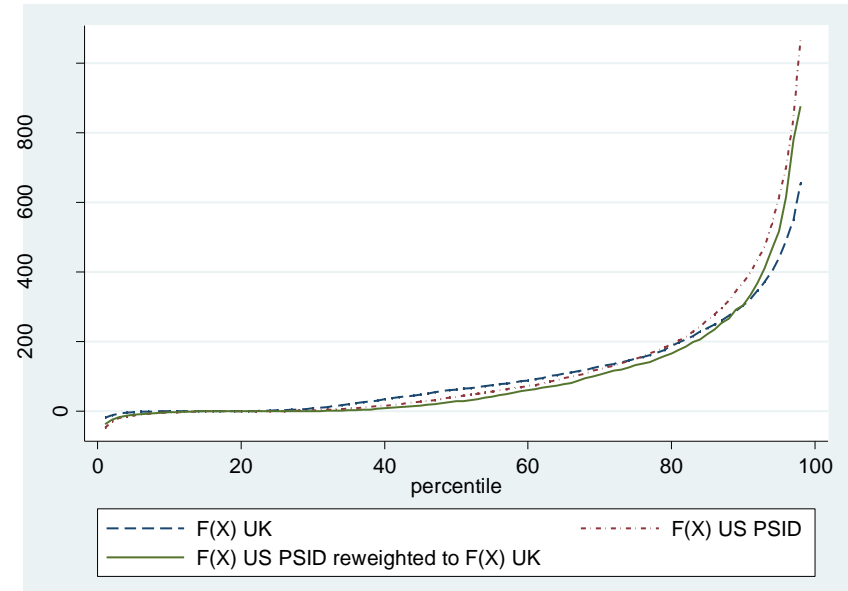

Note: Counterfactual distributional statistics are estimated using the DFL decomposition re-weighting procedure. The explanatory variables included in the reweighting function include age education and working status of the household head, household structure, and household income net of capital gains and interest payments. All counterfactual distributions are estimated using UK as a base country i.e. they represent the distribution that would prevail in each of the countries if the distribution of characteristics was similar to the UK. 


\section{Appendix}

Table A1: Mean and median net worth ${ }^{1}$ by country and household characteristics (thousands 2005 Euros $^{2}$ )

\begin{tabular}{|c|c|c|c|c|c|c|c|c|c|c|c|c|}
\hline \multirow[b]{3}{*}{ Age of household head } & \multicolumn{6}{|c|}{ Mean net worth } & \multicolumn{6}{|c|}{ Median net worth } \\
\hline & UK & Finland & Italy & US SCF & US PSID & Sweden & UK & Finland & Italy & US SCF & US PSID & Sweden \\
\hline & & & & & & & & & & & & \\
\hline $16-24$ & 12.5 & 5.7 & 86.2 & 28.8 & 2.8 & 5.0 & -0.2 & 0.3 & 13.3 & -0.2 & 0.0 & 0.0 \\
\hline $25-34$ & 44.9 & 23.0 & 92.5 & 36.8 & 29.2 & 12.1 & 12.4 & 1.0 & 47.7 & 1.3 & 1.0 & 0.0 \\
\hline $35-44$ & 100.3 & 56.2 & 135.5 & 113.4 & 106.5 & 35.6 & 47.7 & 40.4 & 93.4 & 27.4 & 26.8 & 8.0 \\
\hline $45-54$ & 136.1 & 86.8 & 196.2 & 234.4 & 189.6 & 58.1 & 88.8 & 65.2 & 135.8 & 61.1 & 61.4 & 23.7 \\
\hline $55-64$ & 178.2 & 106.9 & 221.5 & 364.3 & 258.8 & 81.6 & 114.8 & 76.2 & 144.1 & 87.1 & 112.8 & 46.3 \\
\hline $65-74$ & 170.6 & 93.1 & 177.8 & 402.3 & 302.1 & 87.9 & 103.6 & 59.7 & 105.6 & 118.0 & 151.0 & 52.6 \\
\hline $75-84$ & 119.5 & 78.2 & 129.7 & 338.0 & 255.8 & 69.7 & 79.5 & 49.6 & 79.6 & 119.6 & 126.1 & 34.8 \\
\hline $85+$ & 62.5 & 59.3 & 118.6 & 287.0 & 155.9 & 53.7 & 30.3 & 27.1 & 43.8 & 101.3 & 97.4 & 18.4 \\
\hline Household types & & & & & & & & & & & & \\
\hline Single no children & 81.3 & 39.8 & 93.5 & 133.5 & 91.1 & 28.9 & 27.2 & 14.7 & 53.0 & 24.7 & 9.7 & 4.7 \\
\hline Single with children & 59.3 & 22.4 & 98.4 & 37.8 & 28.8 & 16.1 & 4.7 & 1.0 & 53.0 & 0.0 & 0.1 & 0.0 \\
\hline Single with adults & 116.9 & 69.9 & 159.4 & 64.4 & 105.4 & 50.1 & 65.4 & 49.3 & 89.1 & 25.5 & 31.2 & 21.8 \\
\hline Couple no children & 165.8 & 101.1 & 189.0 & 354.3 & 302.6 & 91.1 & 102.1 & 66.2 & 112.3 & 99.7 & 124.7 & 58.8 \\
\hline Couple with children & 111.1 & 71.7 & 167.2 & 180.7 & 161.4 & 59.5 & 54.7 & 55.0 & 111.9 & 34.5 & 43.8 & 25.0 \\
\hline Couples with adults & 177.5 & 120.6 & 224.2 & 313.9 & 175.9 & 101.7 & 122.8 & 89.7 & 160.7 & 98.4 & 112.8 & 66.9 \\
\hline Household head working & & & & & & & & & & & & \\
\hline Working & 117.3 & 72.8 & 168.9 & 181.5 & 139.2 & 48.4 & 61.7 & 47.6 & 111.4 & 32.4 & 31.2 & 14.2 \\
\hline Unemployed/inactive & 64.1 & 14.1 & 146.1 & 94.9 & 55.6 & 8.0 & 1.0 & 0.1 & 69.0 & 0.8 & 0.5 & -1.4 \\
\hline Retired & 139.3 & 75.1 & 161.7 & 370.3 & 283.4 & 65.2 & 86.7 & 53.3 & 101.3 & 128.0 & 146.1 & 29.5 \\
\hline Education of household & & & & & & & & & & & & \\
\hline Low & 89.4 & 56.2 & 111.7 & 85.1 & 82.2 & 39.4 & 45.4 & 43.2 & 74.3 & 19.9 & 19.5 & 13.0 \\
\hline Mid & 135.4 & 56.8 & 174.3 & 148.7 & 130.0 & 41.1 & 76.7 & 30.6 & 116.7 & 33.0 & 38.0 & 9.3 \\
\hline High & 177.6 & 137.6 & 323.4 & 448.9 & 306.6 & 75.0 & 95.3 & 84.9 & 217.5 & 118.0 & 104.2 & 28.1 \\
\hline Homeownership & & & & & & & & & & & & \\
\hline Non-home owners & 5.1 & -2.5 & 13.5 & 6.2 & 7.8 & 1.1 & 0.0 & 0.0 & 2.7 & 0.0 & 0.0 & 0.0 \\
\hline Homeowners & 164.8 & 98.5 & 221.3 & 295.5 & 235.4 & 87.7 & 106.3 & 68.6 & 154.9 & 91.3 & 99.3 & 54.4 \\
\hline Income & & & & & & & & & & & & \\
\hline Bottom & 92.6 & 39.4 & 90.4 & 85.5 & 102.4 & 27.4 & 43.3 & 6.1 & 52.8 & 1.7 & 1.5 & 3.1 \\
\hline $2^{\text {nd }}$ & 79.4 & 48.3 & 120.4 & 97.2 & 86.8 & 34.2 & 28.6 & 31.7 & 84.9 & 18.6 & 19.5 & 7.6 \\
\hline $3^{\text {rd }}$ & 109.6 & 61.6 & 162.7 & 122.8 & 129.8 & 45.0 & 60.0 & 48.6 & 119.9 & 50.5 & 46.8 & 18.4 \\
\hline Top & 182.9 & 105.8 & 282.4 & 415.4 & 298.0 & 92.6 & 109.1 & 78.3 & 195.2 & 142.0 & 129.5 & 53.9 \\
\hline
\end{tabular}

Note: The sample includes households with non-missing data on net worth and the various variables used in the decomposition analysis. Household weights are used. 
Table A2: DFL decomposition of difference in the distribution of different wealth components for owners only

\begin{tabular}{|c|c|c|c|c|c|c|c|c|c|}
\hline \multirow[b]{2}{*}{ UK } & \multicolumn{3}{|c|}{ Net financial wealth } & \multicolumn{3}{|c|}{ Gross financial wealth } & \multicolumn{3}{|c|}{ Financial debt } \\
\hline & $\mathrm{P} 25$ & P50 & P90 & P25 & P50 & P90 & $\mathrm{P} 25$ & P50 & P90 \\
\hline Actual & -0.43 & 4.16 & 72.23 & 1.45 & 8.32 & 82.34 & 0.80 & 3.61 & 19.07 \\
\hline \multicolumn{10}{|l|}{ Finland } \\
\hline Actual & -0.82 & 1.62 & 28.25 & 0.65 & 3.23 & 30.87 & 1.94 & 4.84 & 20.99 \\
\hline Counterfactual & 0.04 & 3.23 & 40.94 & 1.13 & 5.33 & 41.96 & 2.42 & 5.33 & 24.22 \\
\hline \multicolumn{10}{|l|}{ Italy } \\
\hline Actual & 3.18 & 9.55 & 58.34 & 4.24 & 10.61 & 60.60 & 2.55 & 5.30 & 15.91 \\
\hline Counterfactual & 3.18 & 10.61 & 58.34 & 4.24 & 10.72 & 60.99 & 2.33 & 5.30 & 15.91 \\
\hline \multicolumn{10}{|l|}{ US SCF } \\
\hline Actual & -5.01 & 1.58 & 158.26 & 1.46 & 7.44 & 169.47 & 1.95 & 7.93 & 31.24 \\
\hline Counterfactual & -5.97 & 0.76 & 108.11 & 0.98 & 4.87 & 119.85 & 1.66 & 7.14 & 29.22 \\
\hline \multicolumn{10}{|l|}{ US PSID } \\
\hline Actual & -2.14 & 2.92 & 144.14 & 1.56 & 7.79 & 152.91 & 1.95 & 4.87 & 27.27 \\
\hline Counterfactual & -1.89 & 1.95 & 121.74 & 0.97 & 4.87 & 132.45 & 1.17 & 4.58 & 22.40 \\
\hline \multicolumn{10}{|l|}{ Sweden } \\
\hline Actual & - & - & - & 2.34 & 9.02 & 63.45 & - & - & - \\
\hline \multirow[t]{2}{*}{ Counterfactual } & - & - & - & 2.98 & 12.08 & 81.05 & - & - & - \\
\hline & \multicolumn{3}{|c|}{ Net housing wealth } & \multicolumn{3}{|c|}{ Gross housing wealth } & \multicolumn{3}{|c|}{ Housing debt } \\
\hline UK & $\mathrm{P} 25$ & P50 & P90 & $\mathrm{P} 25$ & P50 & P90 & $\mathrm{P} 25$ & P50 & $\mathrm{P90}$ \\
\hline Actual & 49.11 & 92.45 & 288.90 & 82.34 & 130.01 & 332.24 & 36.11 & 57.78 & 124.23 \\
\hline \multicolumn{10}{|l|}{ Finland } \\
\hline Actual & 35.52 & 61.35 & 163.05 & 48.43 & 72.65 & 177.58 & 10.49 & 24.22 & 63.86 \\
\hline Counterfactual & 40.36 & 72.65 & 201.79 & 48.43 & 82.96 & 209.87 & 12.27 & 27.12 & 64.57 \\
\hline \multicolumn{10}{|l|}{ Italy } \\
\hline Actual & 79.56 & 133.66 & 376.58 & 84.86 & 142.15 & 384.00 & 9.55 & 26.52 & 79.56 \\
\hline Counterfactual & 79.56 & 133.66 & 424.31 & 84.86 & 148.51 & 424.31 & 10.61 & 31.82 & 82.74 \\
\hline \multicolumn{10}{|l|}{ US SCF } \\
\hline Actual & 31.17 & 77.14 & 325.85 & 73.04 & 126.61 & 425.60 & 34.09 & 71.56 & 187.97 \\
\hline Counterfactual & 29.22 & 68.18 & 261.11 & 63.50 & 97.39 & 316.52 & 26.30 & 57.46 & 140.05 \\
\hline \multicolumn{10}{|l|}{ US PSID } \\
\hline Actual & 34.09 & 77.91 & 292.18 & 77.91 & 132.45 & 374.96 & 38.96 & 70.12 & 175.31 \\
\hline Counterfactual & 31.17 & 73.04 & 267.83 & 63.31 & 107.13 & 311.65 & 29.22 & 58.44 & 136.35 \\
\hline Sweden & & & & & & & & & \\
\hline Actual & - & - & - & 35.76 & 68.95 & 195.95 & - & - & - \\
\hline Counterfactual & - & - & - & 40.98 & 75.97 & 219.18 & - & - & - \\
\hline & & t worth & & Total gros & vealth & & Total c & & \\
\hline UK & $\mathrm{P} 25$ & P50 & P90 & $\mathrm{P} 25$ & P50 & P90 & $\mathrm{P} 25$ & P50 & P90 \\
\hline Actual & 7.92 & 70.20 & 316.93 & 54.31 & 115.56 & 364.47 & 5.06 & 39.06 & 118.31 \\
\hline Finland & & & & & & & & & \\
\hline Actual & 1.29 & 43.02 & 161.43 & 6.46 & 59.68 & 176.05 & 4.26 & 12.91 & 59.41 \\
\hline Counterfactual & 13.24 & 62.24 & 211.83 & 27.12 & 75.31 & 225.57 & 5.65 & 17.43 & 61.36 \\
\hline Italy & & & & & & & & & \\
\hline Actual & 35.75 & 112.02 & 382.92 & 42.96 & 118.73 & 396.73 & 4.24 & 9.55 & 63.65 \\
\hline Counterfactual & 25.99 & 107.56 & 394.61 & 29.70 & 110.41 & 416.15 & 4.24 & 10.61 & 78.50 \\
\hline US SCF & & & & & & & & & \\
\hline Actual & 1.16 & 48.66 & 430.96 & 19.56 & 102.07 & 537.60 & 7.79 & 37.98 & 163.62 \\
\hline Counterfactual & 0.63 & 38.18 & 322.74 & 13.01 & 86.19 & 377.10 & 5.26 & 23.83 & 129.68 \\
\hline US PSID & & & & & & & & & \\
\hline Actual & 2.82 & 51.62 & 389.86 & 18.50 & 114.44 & 472.35 & 7.79 & 42.85 & 159.72 \\
\hline Counterfactual & 1.02 & 42.07 & 333.08 & 10.03 & 88.14 & 394.44 & 3.90 & 23.37 & 116.87 \\
\hline Sweden & & & & & & & & & \\
\hline Actual & -1.29 & 19.28 & 155.75 & 11.66 & 55.39 & 209.44 & 6.24 & 20.02 & 91.26 \\
\hline Counterfactual & -0.46 & 28.58 & 181.01 & 19.62 & 70.40 & 248.14 & 6.64 & 23.25 & 104.47 \\
\hline
\end{tabular}

Note: Counterfactual distributional statistics are estimated using the DFL decomposition re-weighting procedure. The explanatory variables included in the reweighting function include age education and working status of the household head, household structure, and household income net of capital gains and interest payments. All counterfactual distributions are estimated using UK as a base country. The sample includes households with non-missing data on wealth and in any of the variables used to estimate the weighting function. 
Table A3: DFL decomposition of difference in the distribution of different wealth components for owners only

\begin{tabular}{|c|c|c|c|c|c|c|c|c|c|}
\hline \multirow[b]{2}{*}{ UK } & \multicolumn{3}{|c|}{ Net financial wealth } & \multicolumn{3}{|c|}{ Gross financial wealth } & \multicolumn{3}{|c|}{ Financial debt } \\
\hline & Top $10 \%$ & Top $1 \%$ & Gini & Top $10 \%$ & Top $1 \%$ & Gini & Top $10 \%$ & Top $1 \%$ & Gini \\
\hline Actual & 71.00 & 20.82 & 0.96 & 59.51 & 16.97 & 0.75 & 44.61 & 11.74 & 0.64 \\
\hline \multicolumn{10}{|l|}{ Finland } \\
\hline Actual & 92.03 & 38.06 & 1.38 & 64.50 & 26.11 & 0.77 & 51.57 & 16.67 & 0.63 \\
\hline Counterfactual & 75.08 & 26.56 & 1.13 & 58.31 & 20.18 & 0.74 & 50.20 & 15.09 & 0.62 \\
\hline \multicolumn{10}{|l|}{ Italy } \\
\hline Actual & 62.57 & 26.15 & 0.76 & 60.18 & 25.21 & 0.71 & 36.64 & 10.50 & 0.50 \\
\hline Counterfactual & 62.54 & 27.13 & 0.75 & 60.14 & 26.24 & 0.71 & 37.70 & 6.04 & 0.51 \\
\hline \multicolumn{10}{|l|}{ US SCF } \\
\hline Actual & 90.26 & 50.77 & 1.01 & 82.38 & 45.68 & 0.89 & 47.25 & 19.21 & 0.63 \\
\hline Counterfactual & 91.83 & 44.35 & 1.08 & 79.49 & 38.68 & 0.87 & 41.88 & 11.26 & 0.60 \\
\hline \multicolumn{10}{|l|}{ US PSID } \\
\hline Actual & 86.03 & 39.81 & 1.00 & 77.39 & 35.52 & 0.86 & 53.19 & 18.71 & 0.67 \\
\hline Counterfactual & 88.34 & 43.99 & 1.00 & 80.89 & 39.54 & 0.88 & 52.02 & 15.56 & 0.67 \\
\hline \multicolumn{10}{|l|}{ Sweden } \\
\hline Actual & - & - & - & 56.92 & 21.17 & 0.72 & - & - & - \\
\hline \multirow[t]{2}{*}{ Counterfactual } & - & - & - & 57.30 & 21.73 & 0.72 & - & - & - \\
\hline & \multicolumn{3}{|c|}{ Net housing wealth } & \multicolumn{3}{|c|}{ Gross housing wealth } & \multicolumn{3}{|c|}{ Housing debt } \\
\hline UK & Top $10 \%$ & Top $1 \%$ & Gini & Top 10\% & Top $1 \%$ & Gini & Top $10 \%$ & Top $1 \%$ & Gini \\
\hline Actual & 35.26 & 7.54 & 0.49 & 31.30 & 6.86 & 0.40 & 28.11 & 6.36 & 0.39 \\
\hline \multicolumn{10}{|l|}{ Finland } \\
\hline Actual & 34.18 & 9.50 & 0.47 & 31.19 & 8.31 & 0.41 & 29.02 & 5.26 & 0.44 \\
\hline Counterfactual & 34.29 & 9.28 & 0.46 & 31.72 & 8.18 & 0.42 & 28.66 & 4.30 & 0.43 \\
\hline \multicolumn{10}{|l|}{ Italy } \\
\hline Actual & 34.52 & 8.21 & 0.46 & 33.86 & 7.85 & 0.45 & 32.76 & 3.47 & 0.50 \\
\hline Counterfactual & 35.01 & 8.26 & 0.47 & 34.26 & 7.71 & 0.46 & 27.76 & 2.45 & 0.48 \\
\hline \multicolumn{10}{|l|}{ US SCF } \\
\hline Actual & 53.67 & 21.16 & 0.66 & 47.04 & 17.62 & 0.57 & 38.21 & 10.89 & 0.50 \\
\hline Counterfactual & 46.59 & 17.51 & 0.60 & 40.59 & 14.83 & 0.51 & 32.54 & 8.40 & 0.46 \\
\hline \multicolumn{10}{|l|}{ US PSID } \\
\hline Actual & 46.85 & 16.87 & 0.60 & 38.90 & 12.77 & 0.49 & 28.75 & 6.54 & 0.42 \\
\hline Counterfactual & 42.65 & 14.14 & 0.57 & 37.02 & 11.57 & 0.48 & 27.30 & 4.95 & 0.41 \\
\hline Sweden & & & & & & & & & \\
\hline Actual & - & - & - & 34.87 & 9.53 & 0.48 & - & - & - \\
\hline Counterfactual & - & - & - & 36.07 & 11.03 & 0.49 & - & - & - \\
\hline & & Jet worth & & Tota & gross weal & & & tal debt & \\
\hline UK & Top 10\% & Top $1 \%$ & Gini & Top $10 \%$ & Top $1 \%$ & Gini & Top $10 \%$ & Top 1\% & Gini \\
\hline Actual & 43.61 & 9.48 & 0.64 & 36.90 & 7.85 & 0.53 & 34.84 & 8.21 & 0.56 \\
\hline Finland & & & & & & & & & \\
\hline Actual & 44.84 & 12.71 & 0.68 & 39.40 & 10.95 & 0.58 & 38.25 & 8.26 & 0.57 \\
\hline Counterfactual & 41.02 & 11.28 & 0.62 & 37.24 & 9.93 & 0.55 & 35.81 & 7.39 & 0.56 \\
\hline Italy & & & & & & & & & \\
\hline Actual & 40.34 & 10.27 & 0.57 & 39.41 & 9.99 & 0.56 & 50.93 & 7.99 & 0.62 \\
\hline Counterfactual & 42.17 & 10.64 & 0.59 & 40.96 & 10.21 & 0.57 & 66.85 & 2.95 & 0.61 \\
\hline US SCF & & & & & & & & & \\
\hline Actual & 69.51 & 32.24 & 0.83 & 60.53 & 26.83 & 0.73 & 44.33 & 13.27 & 0.63 \\
\hline Counterfactual & 63.21 & 26.91 & 0.80 & 53.73 & 22.18 & 0.69 & 40.94 & 10.17 & 0.63 \\
\hline US PSID & & & & & & & & & \\
\hline Actual & 61.69 & 24.75 & 0.79 & 51.42 & 19.65 & 0.67 & 36.20 & 8.10 & 0.57 \\
\hline Counterfactual & 61.80 & 24.08 & 0.78 & 53.00 & 20.77 & 0.68 & 36.44 & 7.38 & 0.59 \\
\hline Sweden & & & & & & & & & \\
\hline Actual & 56.67 & 17.10 & 0.88 & 41.95 & 12.37 & 0.60 & 43.39 & 12.77 & 0.61 \\
\hline Counterfactual & 54.79 & 17.35 & 0.83 & 42.11 & 11.61 & 0.59 & 45.20 & 13.52 & 0.62 \\
\hline
\end{tabular}

